\title{
Modelling the mineralogical composition and solubility of mineral dust in the Mediterranean area with CHIMERE 2017r4
}

\author{
Laurent Menut ${ }^{1}$, Guillaume Siour ${ }^{2}$, Bertrand Bessagnet ${ }^{3}$, Florian Couvidat $^{3}$, Emilie Journet ${ }^{2}$, Yves Balkanski $^{4}$, and \\ Karine Desboeufs ${ }^{2}$ \\ ${ }^{1}$ Laboratoire de Météorologie Dynamique, Ecole Polytechnique, IPSL Research University, Ecole Normale Supérieure, \\ Université Paris-Saclay, Sorbonne Universités, UPMC Univ Paris 06, CNRS, Route de Saclay, 91128 Palaiseau, France \\ ${ }^{2}$ Laboratoire Inter-Universitaire des Systèmes Atmosphériques, UMR CNRS 7583, Université Paris Est Créteil et Université \\ de Paris, Institut Pierre Simon Laplace, Créteil, France \\ ${ }^{3}$ Institut National de l'Environnement Industriel et des Risques, Verneuil en Halatte, 60550, \\ Parc Technologique ALATA, France \\ ${ }^{4}$ Laboratoire des Sciences du Climat et de l'Environnement, CNRS, CEA, UVSQ, Gif sur Yvette, France
}

Correspondence: Laurent Menut (menut@1md.polytechnique.fr)

Received: 26 November 2019 - Discussion started: 16 January 2020

Revised: 20 March 2020 - Accepted: 24 March 2020 - Published: 24 April 2020

\begin{abstract}
Modelling of mineral dust is often done using one single mean species. But for biogeochemical studies, it could be useful to access to a more detailed information on differentiated mineral species and the associated chemical composition. Differentiating between mineral species would also induce different optical properties and densities and then different radiative impact, transport and deposition. In this study, the mineralogical differentiation is implemented in the CHIMERE regional chemistry-transport model, by using global databases. The results show that this implementation does not change the results much in terms of aerosol optical depth, surface concentrations and deposition fluxes. But the information on mineralogy, with a high spatial (a few kilometres) and temporal $(1 \mathrm{~h})$ resolution, is now available and is ready to be used for future biogeochemical studies.
\end{abstract}

\section{Introduction}

Mineral dust is a major source of aerosol in the Earth system (Shao et al., 2011). It is studied for many aspects on how it impacts the Earth radiative system, among which is its contribution to the budget of surface aerosol concentrations (and then to air quality and health issues; Morman and Plumlee, 2013) and to the budget of deposited materials over ocean leading to varying biogeochemistry (Ravi et al., 2011).
This aerosol may be transported a long way, and many modelling studies are conducted from the global to the regional scale to better understand its life cycle. Numerous uncertainties remain for all the steps of this life cycle. First, emissions over arid areas depend on soil and surface characteristics as well as near-surface wind speed (Alfaro and Gomes, 2001; Menut et al., 2005; Kok et al., 2012). Second, transport and mixing depend on boundary layer turbulence, troposphere properties, density and shape of the aerosol: the way to model fine plumes in transport models remains poorly known. For example, many studies are dedicated to the transport from Africa to Europe, and the composition and pathways of dust plumes are difficult to predict (Engelstaedter et al., 2006; Bessagnet et al., 2008; Stuut et al., 2009; Menut et al., 2015; Middleton, 2017). Third, mineral dust will end up being removed from the atmosphere through dry and wet deposition. If dry deposition is relatively well known, wet deposition remains a very uncertain problem to model, being very sensitive to the precipitation, to the altitude of the cloud and to the kind of rain compared to the aerosol size distribution. At present, most of the models can provide deposited maps of mineral dust, but they are generally at a low horizontal resolution and for a single species representative of all possible dust compositions.

Experimentally, dust deposition over the Mediterranean Sea was studied by Desboeufs et al. (2018) to identify the 
main sources of measured nutrients and trace metals deposited in Corsica. In several stations in the Western Mediterranean Basin, Fu et al. (2017) also studied composition of deposited fluxes using the CARAGA deposition collectors network: the chemical signature of deposited fluxes allowed the authors to distinguish the anthropogenic origin of samples from the Saharan dust sources.

Modelled deposition fluxes are used for biogeochemical studies. Studies are rare and were mainly done at the global scale as in Sokolik and Toon (1999), Balkanski et al. (2007) and Wang et al. (2015). At the regional scale, Richon et al. (2017) used these fluxes over the Mediterranean Basin to quantify their impact on plankton productivity. At the global scale, this kind of study was performed, for example, by Mahowald et al. (2005), Landing and Paytan (2010), and Ito and Shi (2016), who used the iron content to obtain more realistic results for their biogeochemical cycle studies. More recently, Hamilton et al. (2019) proposed a specific mechanism to describe iron concentrations, from emissions to deposition. In all these studies, as in the review of Mahowald et al. (2018), it appears that a large part of the biogeochemical result uncertainty is due to the difficulty in predicting mineral dust deposition fluxes.

The knowledge of mineral composition may also be a way to improve upon the validation of regional simulations of atmospheric pollutants. In addition to surface mass measurements of non-speciated particulate matter (PM), the cooperative programme for monitoring and evaluation of the long-range transmission of air pollutants in Europe (European Monitoring and Evaluation Programme, EMEP) proposes surface measurements of calcium aerosol content deposition. Dedicated measurements were also done as presented in Guieu et al. (2010) with the European project ADIOS and in Izana, Tenerife (Spain) (Kandler et al., 2007). The comparison between these measurements and model outputs is not straightforward if the aerosol mineralogical composition is not estimated directly at the source. For example, linear relationships were proposed between non-sea-salt calcium, $\mathrm{nsSCa}^{2+}$, surface concentration and the corresponding total mineral dust surface concentration, as [dust] $=\alpha \times$ $\left[\mathrm{nssCa}^{2+}\right]$, where $\alpha$ is a constant factor. Over western Europe, Putaud et al. (2004) suggest $\alpha=4.55$. Over French forests, Lequy et al. (2013) proposed $\alpha=33\left(R^{2}=0.57\right)$ and $\alpha=5\left(R^{2}=0.54\right)$ for the sites of Breuil and Hesse, respectively. A large variability is observed between these few estimations highlighting the interest in following up directly the calcium part of the deposited mineral dust while modelling this aerosol. The mineral composition, with distinct refractive indices for each mineral, is also a way to have more confidence when comparing observed and modelled aerosol optical depth (AOD).

In this study, we present the implementation of the mineralogical composition of mineral dust in the CHIMERE regional chemistry-transport model. In place of a unique dust species (as in all state-of-the-art current models), we calcu- late the following mineral concentrations: calcite, chlorite, feldspar, goethite, gypsum, hematite, illite, kaolinite, mica, quartz, smectite and vermiculite. Our computation includes the explicit chemical composition and solubility of each mineral. In addition, the concentrations and deposition fluxes of the following chemical elements: magnesium, iron, phosphorus, aluminium, calcium, silicon, manganese et potassium are modelled. This implementation is done using the existing datasets of Journet et al. (2014), that until now, has only been used at the global scale. A simulation is performed for the whole year 2012 over a large domain encompassing Africa and Europe. This geographical domain allows us to have the most complete aerosol source estimation as possible and to reproduce correctly all possible transport pathways from the source areas to the Mediterranean Sea. Results are presented through a comparison to surface measurements in terms of atmospheric concentrations and deposition fluxes. This mineral dust speciation allows us to have more details on our ability to correctly model mineral dust.

The measurements used in this study are described in Sect. 2. The models used for the mineral dust speciation are described in Sect. 3. Mineral dust emissions and deposition flux calculation are detailed in Sect. 4. The impact mineralogy has on the modelled mass is quantified in Sect. 5, a comparison to available observations is presented in Sect. 6, and a focus on the modelling of calcium is presented in Sect. 7. The last section presents the conclusions.

\section{The measurement data}

In this study, the model accuracy is quantified using several variables: AOD with the AErosol RObotic NETwork (AERONET) data and PM surface concentrations and deposition fluxes using the EMEP data. Note that a dedicated campaign called ADIOS was performed in 2002 over the Mediterranean Sea (Guieu et al., 2010). In this study, we preferred to model a more recent year, 2012, in order to have more numerous surface station measurements from the AERONET and EMEP networks.

\subsection{Aerosol optical depth with AERONET data}

For the evaluation of the long-range transport of aerosols, including the mineral dust, we use the AERONET photometers measurements to compare the measured and modelled AOD. The aerosol optical properties are compared between observations and model using the AERONET measurements (Holben et al., 2001). The comparison is done using the AOD measured at a wavelength of $\lambda=550 \mathrm{~nm}$ and using the level 2 data. The reason for using these data is to quantify whether the model can correctly transport mineral dust from Africa (main emission sources) to the Mediterranean Sea and to Europe, where the surface concentrations are later compared. Note that we use the same stations as those described 
in Menut et al. (2016). The stations are listed in Table A1, and a map showing their locations is presented Fig. A1.

\subsection{Concentrations and deposition with EMEP data}

For the surface aerosol concentrations evaluation, we use the EMEP network providing measurements of $\mathrm{PM}_{2.5}$ and $\mathrm{PM}_{10}$ (aerosol with a mean mass median diameter less than 2.5 and $10 \mu \mathrm{m}$, respectively), gaseous species such as $\mathrm{NO}_{2}$ and $\mathrm{O}_{3}$, and aerosols including nitrates, ammonium and sulfates. The data are stored in the EBAS database, and information about these measurements is available at https://ebas.nilu.no (last access: 29 November 2019). In addition, and to evaluate the realism of the development of the mineralogical speciation, the non-sea-salt calcium concentrations, $\mathrm{nssCa}^{2+}$, are compared as well as their wet deposition. The list of the selected stations is provided in Table A2 as well as a map showing their locations in Fig. A2.

\section{Modelling}

Simulations are performed in this study using two regional models: (i) the Weather and Research Forecasting (WRF 3.7.1) model calculates the meteorological variables; (ii) the CHIMERE chemistry-transport model (v2017r4) calculates the field concentrations of gases and aerosols based on the 3 -D meteorological fields. The simulation domain has a constant horizontal grid size of $60 \mathrm{~km} \times 60 \mathrm{~km}$. The modelled period extends from 1 January to 31 December 2012.

\subsection{Meteorological modelling}

The meteorological variables are modelled with the nonhydrostatic WRF regional model in its version 3.7.1 (Skamarock et al., 2007). The global meteorological analyses from the National Centers for Environmental Prediction (NCEP) with the Global Forecast System (GFS) products are used to nudge WRF hourly with pressure, temperature, humidity and wind. In order to preserve both large-scale circulations and small-scale gradients and variability, the "spectral nudging" technique was applied (Von Storch et al., 2000). The model is discretised vertically on 28 levels from the surface to $50 \mathrm{hPa}$. The Single Moment- 5 class microphysics scheme is used, allowing for mixed-phase processes and super-cooled water (Hong et al., 2004). The radiation scheme is the RRTMG scheme with the MCICA method of random cloud overlap (Mlawer et al., 1997). The surface layer scheme is based on a Monin-Obukhov with CarlsonBoland viscous sub-layer. The surface physics is calculated using the Noah Land Surface Model scheme with four soil temperature and moisture layers (Chen and Dudhia, 2001). The planetary boundary layer physics is processed using the Yonsei University scheme (Hong et al., 2006), and the cumulus parameterisation uses the ensemble scheme of Grell and
Dévényi (2002). The aerosol direct effect is considered using the Tegen et al. (1997) climatology

\subsection{The chemistry-transport modelling}

CHIMERE is a chemistry-transport model allowing the simulation of gaseous and aerosol species concentration fields at a regional scale. It is an offline model, driven by precalculated meteorological fields. In this study, the version $2017 \mathrm{r} 4$ described in Mailler et al. (2017) is used. Although the simulation is performed on the same horizontal domain and grid between WRF and CHIMERE, the 28 vertical levels of the WRF simulations are projected onto 20 levels from the surface up to $200 \mathrm{hPa}$ for the CHIMERE model.

A complete chemistry is included in the model; a general description of gaseous and aerosol schemes is provided in Mailler et al. (2017) for this model version, including a detailed description of the aerosol scheme in Couvidat et al. (2018). The chemical evolution of gaseous species is calculated using the MELCHIOR2 scheme. The aerosol size distribution is represented using 10 bins, from $40 \mathrm{~nm}$ to $40 \mu \mathrm{m}$, in mean mass median diameter as described in Menut et al. (2016) and updated in Mailler et al. (2017).

The photolysis rates are explicitly calculated using the FastJX radiation module (version 7.0b) (Wild et al., 2000; Bian et al., 2002). The modelled AOD is calculated by FastJX for the several wavelengths over the whole atmospheric column. As limit conditions, climatologies from global model simulations are used at the boundaries of the domain. In this study, outputs from LMDz-INCA (Hauglustaine et al., 2014) provided all gaseous and aerosol species except for mineral dust, for which the simulations from the GOCART model are used (Ginoux et al., 2001). Anthropogenic emissions are prescribed from the Hemispheric Transport of Air Pollution (HTAP) global database (Janssens-Maenhout et al., 2015). The vegetation fire emissions are quantified using the APIFLAME model described in Turquety et al. (2014) and used, for example, in Rea et al. (2015). They are calculated based on the MODIS area burnt product MCD64 (Giglio et al., 2010).

\subsection{Calculation of deposition}

Aerosols, including mineral dust, may be dry or wet deposited, depending on the meteorology and the surface characteristics. The dry-deposition velocity is estimated following Zhang et al. (2001):

$v_{\mathrm{d}}=v_{\mathrm{s}}+\frac{1}{r_{\mathrm{a}}+r_{\mathrm{s}}}$,

with $v_{\mathrm{s}}$ the settling velocity, $r_{\mathrm{a}}$ the aerodynamical resistance depending on the turbulence close to the surface and $r_{\mathrm{s}}$ the surface resistance, depending on the vegetation type. The aerodynamical resistance $r_{\mathrm{a}}$ depends on several turbulent parameters, such as the Monin-Obukhov length $L$, the friction velocity $u_{*}$ and the dynamical roughness length $z_{0 \mathrm{~m}}$. 
Depending on the atmospheric surface layer stability, $r_{\mathrm{a}}$ is estimated in the following two ways, depending on the atmospheric stability:

$$
\begin{cases}r_{\mathrm{a}}(\text { stable })= & \frac{1}{k u_{*}}\left[\ln \left(\frac{z}{z_{0 \mathrm{~m}}}\right)+4.7\left(\zeta_{r}-\zeta_{0}\right)\right] \\ r_{\mathrm{a}}(\text { unstable })= & \frac{1}{k u_{*}}\left[\ln \left(\frac{z}{z_{0 \mathrm{~m}}}\right)+\ln \left(\frac{\left(\eta_{0}^{2}+1\right)\left(\eta_{0}+1\right)^{2}}{\left(\eta_{\mathrm{r}}^{2}+1\right)\left(\eta_{\mathrm{r}}+1\right)^{2}}\right),\right. \\ & \left.+2\left(\tan ^{-1} \eta_{\mathrm{r}}-\tan ^{-1} \eta_{0}\right)\right]\end{cases}
$$

where $z_{\mathrm{r}}$ is a reference height taken at the middle of the first vertical model layer, $\eta_{0}=\left(1-15 \zeta_{0}\right)^{1 / 4}, \eta_{\mathrm{r}}=\left(1-15 \zeta_{\mathrm{r}}\right)^{1 / 4}$ and $\zeta_{0}=z_{0} / L, \zeta_{\mathrm{r}}=z_{\mathrm{r}} / L, k=0.41$ is the von Karman constant, and $L$ the Monin-Obukhov length. $z_{0}$, the dynamical roughness length, depends on the fraction of land use for each category and on the season (see Menut et al., 2013a, for details and values).

The surface resistance $r_{\mathrm{s}}$ for aerosols follows the scheme of Zhang et al. (2001) and is calculated as

$$
r_{\mathrm{s}}=\frac{1}{\epsilon_{0} \cdot u_{*} \cdot R_{1} \cdot\left(E_{\mathrm{B}}+E_{\mathrm{IM}}+E_{\mathrm{IN}}\right)},
$$

with $\epsilon_{0}$ a constant set to $\epsilon_{0}=3$, for all land use categories, $R_{1}$ a correction factor describing the relative amount of aerosols sticking to the surface, $E_{\mathrm{B}}$ the collection efficiency from Brownian diffusion, $E_{\mathrm{IM}}$ the collection efficiency from impaction, and $E_{\mathrm{IN}}$ the collection efficiency from interception. The $R_{1}$ factor is estimated following Slinn (1982):

$R_{1}=\exp \left(-\mathrm{St}^{1 / 2}\right)$

where this factor is applied only for particles with $D_{\mathrm{p}}>$ $5 \mu \mathrm{m}$. For Brownian diffusion, the resistance is estimated as

$$
E_{\mathrm{B}}=\mathrm{Sc}^{-\gamma}
$$

where $\gamma$ is a constant depending on the land use type. In the model, this constant varies between 0.54 and 0.58 . For the impaction, the resistance can have a lot of definitions, depending on the land use. By default, the resistance value used is

$E_{\mathrm{IM}}=\left(\frac{\mathrm{St}}{\alpha+\mathrm{St}}\right)^{2}$.

The $\alpha$ values are land use dependent and are tabulated following Zhang et al. (2001). In this model version, a distinction is made between the Northern and the Southern Hemisphere, in order to use the correct $\alpha$ for a specific modelled day. For specific vegetation types, the formulation is changed. For high vegetation (such as forests), the resistance proposed by Giorgi (1986) is used:

$$
E_{\mathrm{IM}}=\left(\frac{\mathrm{St}}{0.6+\mathrm{St}}\right)^{3.2} \text {. }
$$

For grassland vegetation, a parameterisation is proposed by Davidson et al. (1982):

$$
E_{\mathrm{IM}}=\frac{\mathrm{St}^{3}}{\mathrm{St}^{3}+0.753 \mathrm{St}^{2}+2.796 \mathrm{St}-0.202} .
$$

Finally, the collection efficiency from interception is calculated as

$$
E_{\mathrm{IM}}=\frac{1}{2}\left(\frac{D_{\mathrm{p}}}{A}\right)^{2},
$$

with $A$ a characteristic diameter given for land use and seasonal categories. The settling velocity $v_{\mathrm{s}}$ represents the effect of gravity on particles and is calculated as

$v_{\mathrm{s}}=\frac{1}{18} \frac{D_{\mathrm{p}}^{2} \rho_{\mathrm{p}} g C_{\mathrm{c}}}{\mu}$,

with $\rho_{\mathrm{p}}$ being the particle density, $D_{\mathrm{p}}$ the mass median diameter of particles, and $C_{\mathrm{c}}$ a slip correction factor accounting for the non-continuum effects when $D_{\mathrm{p}}$ becomes smaller and of the same order of magnitude as the mean free path of air, $\lambda$ (Seinfeld and Pandis, 1998). $g$ is the gravitational acceleration with $g=9.81 \mathrm{~ms}^{-2}$, and $\mu$ the dynamic viscosity (here the air dynamic viscosity is set to $\mu_{\text {air }}=1.8 \times$ $\left.10^{-5} \mathrm{~kg} \mathrm{~m}^{-1} \mathrm{~s}^{-1}\right)$. The slip correction factor $C_{\mathrm{c}}$ is estimated as

$C_{\mathrm{c}}=1+\frac{2 \lambda}{D_{\mathrm{p}}}\left[1.257+0.4 \exp \left(-\frac{1.1 D_{\mathrm{p}}}{2 \lambda}\right)\right]$,

with $\lambda$ being the mean free path of air, in metres, estimated as

$\lambda=\frac{2 \mu_{\mathrm{air}}}{p \sqrt{\frac{8 M_{\mathrm{air}}}{\pi R T}}}$,

where $M_{\text {air }}$ is the molecular mass of dry air (here $\left.28.8 \mathrm{~g} \mathrm{~mol}^{-1}\right), T$ the temperature $(\mathrm{K}), p$ the pressure $(\mathrm{Pa})$, $\mu$ the air dynamic viscosity and $R$ the universal gas constant.

The aerosol wet-deposition calculation is separated between rain and snow. There is also a distinction between the wet deposition in cloud and below cloud.

For below-cloud scavenging, aerosols are scavenged by raindrops. Following Willis and Tattelman (1989), a polydisperse distribution of raining drops is applied:

$$
\begin{gathered}
N(R)=1.06 \times 10^{14} \cdot P^{-0.0295}(2 R)^{2.16} \\
\cdot \exp \left(-5679 \cdot P^{-0.153} 2 R\right),
\end{gathered}
$$

with $P$ being the precipitation rate in millimetres per hour and $R$ the radius of the droplet (in metres). The flux of deposition is calculated with

$F_{b c}^{i}=c^{i} \cdot \sum_{R} \pi R^{2} u_{g}(R) E\left(R, r_{i}\right) N(R)$,

with $i$ being the aerosol species, $r_{1}$ the radius of the particle (in metres), $u_{g}$ the terminal drop velocity (in metres per second), $E\left(R, r_{1}\right)$ the collision efficiency of a particle with a raindrop, and $N(R)$ (in metres to the power of four) the raindrop size distribution. 
For below-cloud scavenging of particles by snow, the particles are scavenged by applying the parameterisation of Wang et al. (2014). A scavenging coefficient $\lambda_{\text {snow }}$ is computed with

$\log \left(\lambda_{\text {snow }}\right)=\log A+B$,

with $A$ and $B$ being fit function depending on the aerosol mean mass median diameter $D_{\mathrm{p}}$. The flux of deposition is calculated with

$F_{\text {in }}^{i}=-\lambda_{\text {snow }} \cdot c^{i}$.

In-cloud scavenging is here considered only when a precipitation occurs. The rate of deposition is computed by calculating the rate of impaction between hydrometeors and cloud droplets (assumed to have a diameter of $10 \mu \mathrm{m}$ ). The rate of scavenging is computed with Eqs. (14) and (16) for $D_{\mathrm{p}}=10 \mu \mathrm{m}$.

\subsection{The mineral dust flux calculation}

In the original version of the model, one unique vertical flux of emissions is estimated for a mean averaged species representing all dust species and elements. Emissions are calculated using the Alfaro and Gomes (2001) scheme, optimised following Menut et al. (2005) and using the soil and surface databases presented in Menut et al. (2013b). Since this latter article was published, several changes have been implemented in the emissions scheme.

For the erodibility, the original scheme takes into account United States Geological Survey (USGS) land use only. In this model version, we added the database proposed by Beegum et al. (2016) to calculate a new erodibility factor, more related to arid areas. For all model cells regarded as "desert", the MODIS erodibility is used, while for all other cells, a constant erodibility factor is applied depending on the USGS land use, as in Menut et al. (2013b). This enables us to have a more realistic description of the erodibility in arid areas.

In order to take into account the rain effect on mineral dust emission limitation, a "memory" function is added. During a precipitation event, the surface emission fluxes are set to zero. After the precipitation event, a smooth function is applied to account for a possible crust at the surface (and thus fewer emissions). The complete restart of emissions is obtained $12 \mathrm{~h}$ after the end of a precipitating event, a timing close to the last results found by Lohou et al. (2014). This function is presented in Mailler et al. (2017) and does not take into account the land use variability.

\section{Model changes for mineral dust mineralogy}

This section presents all changes made in the CHIMERE v2017r4 model, in order to take into account the calculation of mineral dust mineralogy. We describe a methodology which permits us to split the vertical flux into contributions of differentiated mineral species. The calculation of the chemical composition of the mineral dust is presented. Boundary conditions and deposition fluxes are also described. The distinction between mineralogical species is estimated after the emission flux calculations. The mineral properties are considered to have a negligible impact on the emission flux itself.

\subsection{Mineralogical species information}

In order to split the emission flux into several mineral and chemical elements, additional information is required:

- soil databases describing the relative part of each mineral and each chemical element in each model grid cell

- the relative part of clay and silt in each grid cell

- for each mineral, its density and refractive index

- the solubility of each chemical element as a function of each mineralogical species.

We describe below how we use information from already known and published databases to gather these data.

\subsubsection{Silt-clay partition and density}

In order to have information on the dust mineralogical composition, the global databases presented in Journet et al. (2014) are used. These databases are delivered with a horizontal resolution of $0.5^{\circ} \times 0.5^{\circ}$ and are then interpolated on the model grid used in this study. Data are provided for 12 different species, listed in Table 1. For each mineral, we indicate if it can be found in the clay or silt fraction of the soils. The density of each is also provided: this information comes from several references, including Perlwitz et al. (2015). These values for densities have a non-negligible but not quantified uncertainty. For each mineral, the reference (peer-reviewed publication or internet database) is specified in the table. Note that for the Mica density, being a group of numerous minerals, the density of muscovite is used.

Only five mineralogical species appear in both clay and silt soil fractions: calcite, chlorite, feldspar, goethite and quartz. Two species appear only in the silt fraction: gypsum and mica. Finally, five species are only present in the clay fraction: hematite, illite, kaolonite, smectite and vermiculite. As an example of a relative part of a mineral in silt and clay soil, Fig. 1 presents the abundance of quartz over the horizontal domain used in this study. It is shown that even if quartz enters into the composition of both silt and clay, it dominates the silt fraction.

\subsubsection{Refractive indices}

In order to be consistent with the approach that includes the mineralogy, we need to know the refractive indices (real and 


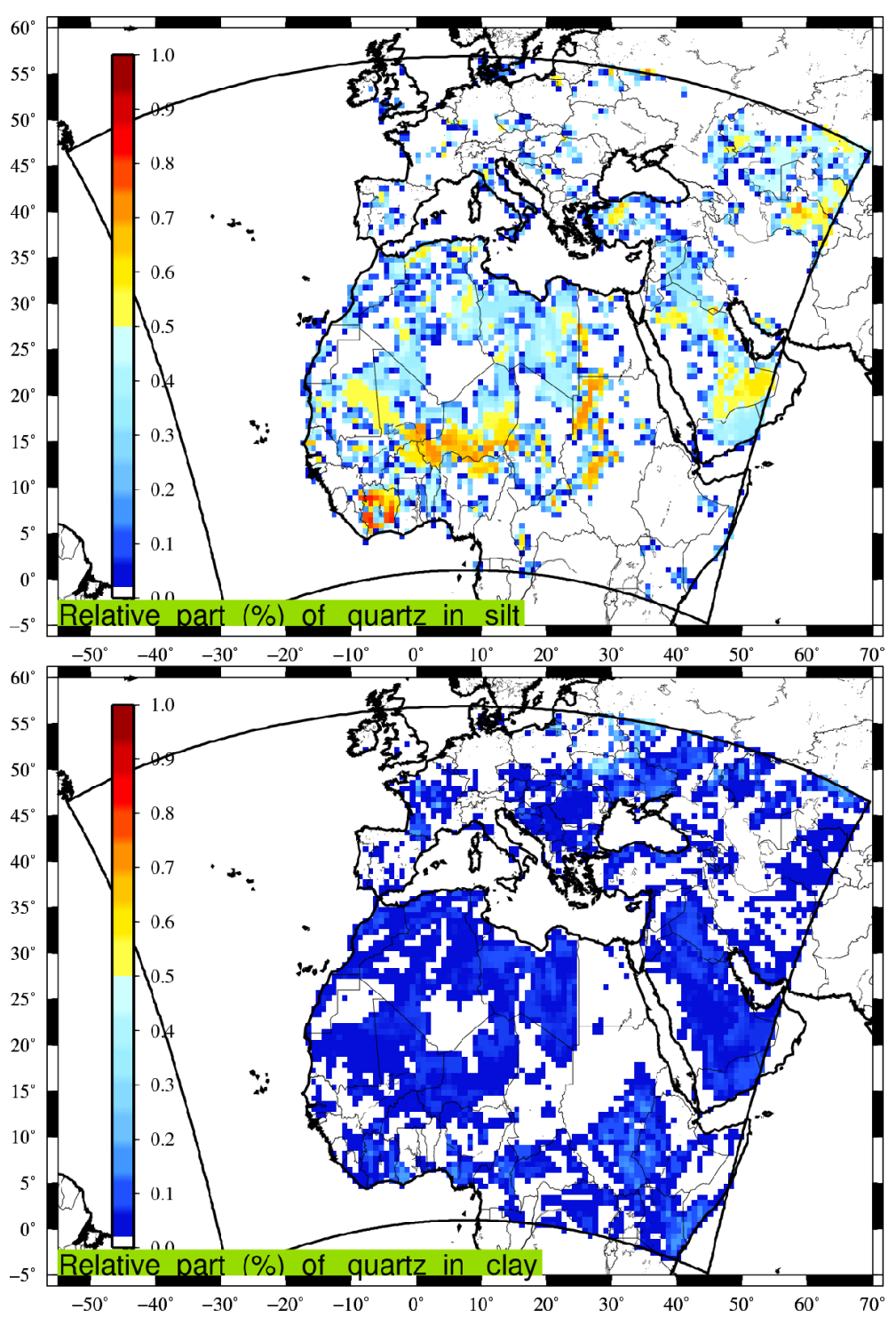

Figure 1. Example of the relative part $(0: 1)$ of the quartz mineral in the silt and clay fraction of the soil.

imaginary parts) for each mineral. Values of refractive indices can be gathered from several publications such as Kandler et al. (2007), Utry et al. (2015) and Scanza et al. (2015). As information on the variability of the imaginary part was missing from these references, we use the data of Scanza et al. (2015) in our study and for the following minerals: smectite, illite, hematite, feldspar, kaolinite, calcite, quartz and gypsum. For the goethite, we use the data reported in Bedidi and Cervelle (1993). For chlorite and mica, and in the absence of accurate information, we use the kaolinite refractive index. For vermiculite, being mainly included in the clay fraction, composed of iron, we use the montmorillonite refractive index (also found in Scanza et al., 2015).

Values of the real and imaginary parts of the refractive indices are presented in Fig. 2 as a function of the solar radiation wavelength (micrometre). In addition to the individual minerals, the model species DUST is added. This "mean" species corresponds to what is usually used in models having only one lump species for the mineral dust. All values are reported in Table 2 . The refractive indices of the mineralogical species modelled here are presented in Table 2. Data are shown for five wavelengths, which are the ones chosen to run the FastJX radiative transfer model, implemented online in CHIMERE. For each species and each wavelength, the real and imaginary parts of the refractive index are displayed.

\subsection{Chemical composition}

For each mineral species, we estimate the chemical element composition for the following eight elements: magnesium $(\mathrm{Mg})$, phosphorus $(\mathrm{P})$, calcium $(\mathrm{Ca})$, manganese $(\mathrm{Mn})$, iron $(\mathrm{Fe})$, aluminium $(\mathrm{Al})$, silicon $(\mathrm{Si})$ and potassium $(\mathrm{K})$. This 
Table 1. List of mineral species used in this study (in alphabetical order). Their possible presence in the soil fraction that consists of silt and clay is also indicated. Densities in grams per centimetre cubed. For the Mica density, being a group of numerous minerals, the density of muscovite is used.

\begin{tabular}{lllll}
\hline Number & Mineral & Silt & Clay & Density \\
\hline 1 & calcite & $\sqrt{ }$ & $\sqrt{ }$ & $2.71^{\mathrm{a}}$ \\
2 & chlorite & $\sqrt{ }$ & $\sqrt{ }$ & $2.42^{\mathrm{c}}$ \\
3 & feldspar & $\sqrt{ }$ & $\sqrt{ }$ & $2.68^{\mathrm{a}}$ \\
4 & goethite & $\sqrt{ }$ & & $4.18^{\mathrm{b}}$ \\
5 & gypsum & $\sqrt{ }$ & & $2.30^{\mathrm{b}}$ \\
6 & hematite & & $\sqrt{ }$ & $5.25^{\mathrm{b}}$ \\
7 & illite & & $\sqrt{ }$ & $2.57^{\mathrm{a}}$ \\
8 & kaolinite & & $\sqrt{ }$ & $2.63^{\mathrm{a}}$ \\
9 & mica & $\sqrt{ }$ & & $2.81^{\mathrm{c}}$ \\
10 & quartz & $\sqrt{ }$ & $\sqrt{ }$ & $2.67^{\mathrm{a}}$ \\
11 & smectite & & $\sqrt{ }$ & $2.57^{\mathrm{a}}$ \\
12 & vermiculite & & $\sqrt{ }$ & $2.30^{\mathrm{c}}$ \\
\hline
\end{tabular}

${ }^{a}$ Perlwitz et al. (2015). ${ }^{b}$ http://www.mindat.org (last access: 29 November 2019). ${ }^{\mathrm{c}} \mathrm{http}$ :

//www.engineeringtoolbox.com/mineral-density-d_1555.html (last access: 29 November 2019).

information was collected from the following previous studies: Kandler et al. (2007), Journet et al. (2014) and Zhang et al. (2015). Values computed in this study are a combination of Journet et al. (2014) and Zhang et al. (2015) and are presented in Table 3 . The solubility is also provided as a percentage of each chemical element in each mineral.

\subsection{Redistribution of emissions and deposition fluxes}

The calculation of the mineralogy and chemical elements is divided into two parts.

1. The emission fluxes: as described in Sect. 4, the vertical flux of emitted mineral dust is calculated once, independently of the mineralogy. From this flux, fluxes are calculated for the several mineralogical species. In each grid cell and for each aerosol bin, instead of having only one mean dust species (called DUST), the emission fluxes corresponding to 12 species are computed (all minerals, i.e. DuSmec, DuIlli and so on) plus the remaining flux that cannot be attributed to a specific mineral (DuOT for "other").

2. The deposition fluxes: after emission and transport of the mineralogical species, the calculation is refined for the deposition - fluxes of the chemical elements are estimated for each chemical species, and their soluble and insoluble parts are computed separately. This distinction is of interest when, for example, comparing calcium measurements over land and biogeochemistry over sea. In this case, we calculate the deposition flux for the emitted species (i.e. DuSmec, DuIlli, DuOT)
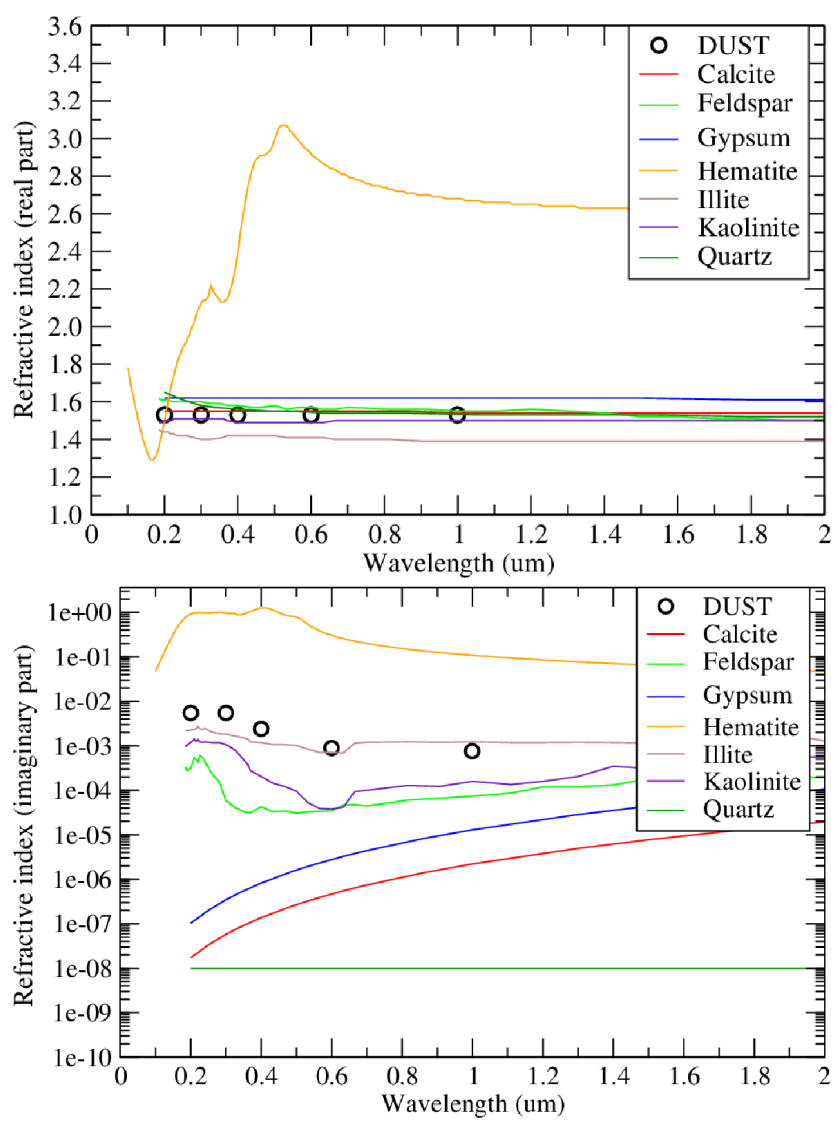

Figure 2. Refractive indices (real and imaginary parts, no unit) for the modelled minerals. DUST corresponds to the model species representing a mean mineral dust.

plus the deposition fluxes for their chemical composition (DuFeSo, DuFeIn, etc.).

In addition, one has to note that the boundary conditions for mineral dust are entirely assigned to the other species, DuOT. Indeed, having no information from the global model used for the boundary conditions, it was not possible to assign these concentrations to specific minerals. To minimise the impact of this approximation on the boundary conditions, the simulations used in this study are done over a large domain.

\subsubsection{Emission fluxes}

For the emission fluxes, several specific steps are taken to derive estimates of

- the relative part of clay and silt in each model grid cell,

- the relative part of each mineralogical species, as a function of its relative part of clay and silt,

- the rest of the mass, not attributed to clay and silt, thus to a mineralogical species. 
Table 2. Values of refractive indices (Real, Re, and Imaginary, Im, parts) selected for the 12 mineralogical species and for the five tabulated wavelengths, $\lambda$, required by the FastJX optical properties model.

\begin{tabular}{|c|c|c|c|c|c|c|c|c|c|c|c|c|}
\hline \multirow[b]{2}{*}{$\lambda(\mathrm{nm})$} & \multicolumn{2}{|r|}{ Smectite } & \multicolumn{2}{|r|}{ Illite } & \multicolumn{2}{|c|}{ Hematite } & \multicolumn{2}{|c|}{ Feldspar } & \multicolumn{2}{|c|}{ Kaolinite } & \multicolumn{2}{|r|}{ Calcite } \\
\hline & $\operatorname{Re}$ & $\operatorname{Im}(x-1)$ & $\operatorname{Re}$ & $\operatorname{Im}(x-1)$ & $\mathrm{Re}$ & $\operatorname{Im}(x-1)$ & $\mathrm{Re}$ & $\operatorname{Im}(x-1)$ & $\operatorname{Re}$ & $\operatorname{Im}(x-1)$ & $\mathrm{Re}$ & $\operatorname{Im}(x-1)$ \\
\hline 200 & 1.57 & $3.98 \times 10^{-3}$ & 1.44 & $2.29 \times 10^{-3}$ & 1.49 & $9.13 \times 10^{-1}$ & 1.61 & $3.16 \times 10^{-4}$ & 1.50 & $1.20 \times 10^{-3}$ & 1.55 & $1.72 \times 10^{-8}$ \\
\hline 300 & 1.56 & $4.37 \times 10^{-3}$ & 1.40 & $1.82 \times 10^{-3}$ & 2.12 & $9.73 \times 10^{-1}$ & 1.60 & $5.89 \times 10^{-5}$ & 1.51 & $1.07 \times 10^{-3}$ & 1.55 & $5.81 \times 10^{-8}$ \\
\hline 400 & 1.54 & $3.16 \times 10^{-3}$ & 1.42 & $1.18 \times 10^{-3}$ & 2.37 & $1.25 \times 10$ & 1.58 & $4.27 \times 10^{-5}$ & 1.49 & $2.04 \times 10^{-4}$ & 1.55 & $1.38 \times 10^{-7}$ \\
\hline 600 & 1.52 & $7.59 \times 10^{-4}$ & 1.41 & $7.08 \times 10^{-4}$ & 2.93 & $3.12 \times 10^{-1}$ & 1.57 & $3.47 \times 10^{-5}$ & 1.49 & $3.80 \times 10^{-5}$ & 1.55 & $3.60 \times 10^{-7}$ \\
\hline 999 & 1.51 & $9.33 \times 10^{-4}$ & 1.39 & $1.20 \times 10^{-3}$ & 2.68 & $1.11 \times 10^{-1}$ & 1.56 & $6.61 \times 10^{-5}$ & 1.50 & $1.23 \times 10^{-4}$ & 1.55 & $1.40 \times 10^{-6}$ \\
\hline \multirow[b]{2}{*}{$\lambda(\mathrm{nm})$} & \multicolumn{2}{|r|}{ Quartz } & \multicolumn{2}{|c|}{ Gypsum } & \multicolumn{2}{|c|}{ Vermiculite } & \multicolumn{2}{|c|}{ Chlorite } & \multicolumn{2}{|c|}{ Goethite } & \multicolumn{2}{|r|}{ Mica } \\
\hline & $\operatorname{Re}$ & $\operatorname{Im}(x-1)$ & $\operatorname{Re}$ & $\operatorname{Im}(x-1)$ & $\mathrm{Re}$ & $\operatorname{Im}(x-1)$ & $\mathrm{Re}$ & $\operatorname{Im}(x-1)$ & $\operatorname{Re}$ & $\operatorname{Im}(x-1)$ & $\operatorname{Re}$ & $\operatorname{Im}(x-1)$ \\
\hline 200 & 1.65 & $1.00 x$ & 1.62 & $1.03 \times 10^{-7}$ & 1.57 & $3.98 \times 10^{-3}$ & 1.50 & $1.20 \times 10^{-3}$ & 2.43 & $10^{-2}$ & 1.50 & $1.20 \times 10^{-3}$ \\
\hline 300 & 1.58 & $1.00 \times 10^{-8}$ & 1.62 & $3.47 \times 10^{-7}$ & 1.56 & $4.37 \times 10^{-3}$ & 1.51 & $1.07 \times 10^{-3}$ & 2.43 & $7.00 \times 10^{-2}$ & 1.51 & $1.07 \times 10^{-3}$ \\
\hline 400 & 1.56 & $1.00 \times 10^{-8}$ & 1.62 & $8.23 \times 10^{-7}$ & 1.54 & $3.16 \times 10^{-3}$ & 1.49 & $2.04 \times 10^{-4}$ & 2.43 & $7.00 \times 10^{-2}$ & 1.49 & $2.04 \times 10^{-4}$ \\
\hline 600 & 1.55 & $1.00 \times 10^{-8}$ & 1.62 & $2.14 \times 10^{-6}$ & 1.52 & $7.59 \times 10^{-4}$ & 1.49 & $3.80 \times 10^{-5}$ & 2.10 & $8.80 \times 10^{-2}$ & 1.49 & $3.80 \times 10^{-5}$ \\
\hline 999 & 1.54 & $1.00 \times 10^{-8}$ & 1.62 & $8.21 \times 10^{-6}$ & 1.51 & $9.33 \times 10^{-4}$ & 1.50 & $1.23 \times 10^{-4}$ & 2.10 & $8.80 \times 10^{-2}$ & 1.50 & $1.23 \times 10^{-4}$ \\
\hline
\end{tabular}

The relative part of clay and silt for each mineral depends on the mean mass median diameter of the emitted aerosol. We attempted to follow the formulation proposed in Scanza et al. (2015), with an equation and corresponding results in a table. Unfortunately, the coding of the proposed formulation provides erroneous values, largely different from the results presented in their table. Their formulation appears to be numerically incorrect or in any case far from the simple goal, which is to have a factor giving a smooth transition between 0 and 1 . We thus define a new and simplified formulation as

$\left\{\begin{array}{l}f_{\text {clay }}^{b}=1-\frac{c_{c}}{c_{a} \cdot \exp \left(-c_{b} \cdot D_{\mathrm{p}}^{b}\right)}, \\ f_{\text {silt }}^{b}=1-f_{\text {clay }}^{b}\end{array}\right.$

with $b$ being the aerosol bin number, $D_{\mathrm{p}}$ in micrometres, $c_{a}=20.0, c_{b}=1.2$ and $c_{c}=0.6$. These three coefficients were chosen to retrieve results close to the ones presented in the table of Scanza et al. (2015). The values found with this formulation are displayed in Fig. 3. Note that the values correspond to the 10 bins defined in this study. The intervals correspond to the values of Scanza et al. (2015).

Using the relative part of minerals in the clay and silt fraction of the soil, the emission flux for clay and silt fractions is calculated as

$\left\{\begin{array}{l}E_{\text {clay }}^{b}=f_{\text {clay }}^{b} \cdot E_{\text {tot }}^{b} \\ E_{\text {silt }}^{b}=f_{\text {silt }}^{b} \cdot E_{\text {tot }}^{b}\end{array}\right.$,

with $E_{\text {tot }}$ the total vertical emission flux. For each mineral species and using the values of Table 3, the emission flux is thus estimated as

$\mathrm{EF}_{M}^{b}=E_{\text {clay }}^{b} \cdot \%_{\text {clay } M}+E_{\text {silt }}^{b} \cdot \%_{\text {silt } M}$,

with $\mathrm{EF}_{M}^{b}$ the emission flux for the mineral $M$ (i.e. smectite, illite, etc.) and the bin $b . \%_{\text {clay } M}$ and $\%_{\text {silt } M}$ are the percentage of clay and silt, respectively, in the mineral $M$.

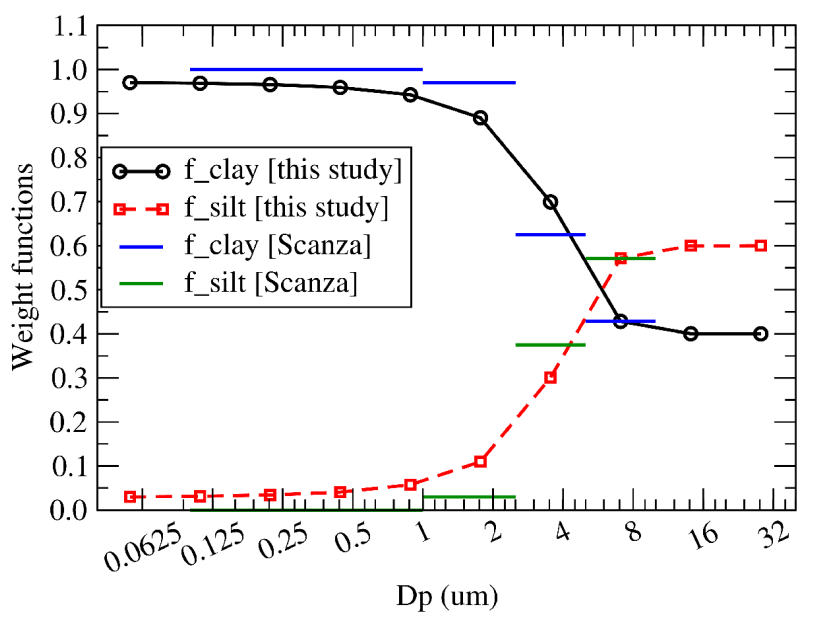

Figure 3. Weight function $(0: 1)$ defined to split the relative part of clay and silt as a function of the aerosol mean mass median diameter $D_{\mathrm{p}}$.

Finally, and since the total percentage of all minerals accounted for did not account for $100 \%$ of the emitted mass in each model grid cell, the rest of the emitted mass is estimated as

$\mathrm{EF}_{\text {other }}^{b}=\mathrm{EF}_{\text {tot }}^{b}-\sum_{i=1}^{M}\left(\mathrm{EF}_{i}^{b}\right)$.

\subsubsection{Deposition fluxes}

The deposition flux of each emitted and transported mineral species is then estimated. In addition, we calculate the flux of the chemical elements pertaining to these mineral species. As described in Table 3 , it is possible to assign a relative percentage of each chemical element in each mineral as well as the relative percentage of solubility. The deposition flux 
Table 3. Generalised chemical compositions and elemental solubility as a percentage of the element contained in the minerals after Paris et al. (2011), Journet et al. (2014) and Zhang et al. (2015).

\begin{tabular}{|c|c|c|c|c|c|c|c|c|}
\hline \multicolumn{9}{|c|}{ Chemical composition (\%) } \\
\hline Mineral & $\mathrm{Mg}$ & $\mathrm{P}$ & $\mathrm{Ca}$ & $\mathrm{Mn}$ & $\mathrm{Fe}$ & $\mathrm{Al}$ & $\mathrm{Si}$ & $\mathrm{K}$ \\
\hline Smectite & 1.21 & 0.17 & 0.91 & 0.03 & 2.55 & 8.57 & 27.44 & 0.27 \\
\hline Illite & 0.85 & 0.09 & 1.45 & 0.03 & 4.01 & 10.47 & 24.11 & 4.28 \\
\hline Hematite & 0.09 & 0.18 & 0.12 & 0.07 & 57.5 & 2.67 & 2.11 & 0.07 \\
\hline Feldspar & 0.15 & 0.09 & 3.84 & 0.01 & 0.34 & 10.96 & 25.24 & 5.08 \\
\hline Kaolinite & 0.02 & 0.16 & 0.03 & 0.01 & 0.24 & 20.42 & 20.27 & 0.00 \\
\hline Calcite & 0.00 & 0.00 & 40.0 & 0.00 & 0.00 & 0.00 & 0.00 & 0.00 \\
\hline Quartz & 0.00 & 0.00 & 0.00 & 0.00 & 0.00 & 0.00 & 46.70 & 0.00 \\
\hline Gypsum & 0.00 & 0.00 & 23.3 & 0.00 & 0.00 & 0.00 & 0.00 & 0.00 \\
\hline Vermiculite & 0.31 & 0.05 & 0.98 & 0.07 & 6.70 & 6.84 & 16.09 & 3.21 \\
\hline Chlorite & 9.26 & 0.00 & 0.38 & 0.23 & 12.5 & 6.48 & 15.69 & 0.00 \\
\hline Goethite & 0.07 & 0.05 & 0.02 & 0.86 & 62.8 & 0.55 & 0.89 & 0.00 \\
\hline Mica & 0.94 & 0.00 & 0.01 & 0.00 & 0.64 & 18.16 & 20.72 & 8.40 \\
\hline \multicolumn{9}{|c|}{ Elemental solubility (\%) } \\
\hline Mineral & $\mathrm{Mg}$ & $\mathrm{P}$ & $\mathrm{Ca}$ & Mn & $\mathrm{Fe}$ & $\mathrm{Al}$ & $\mathrm{Si}$ & K \\
\hline Smectite & 14.09 & 2.93 & 79.20 & 25.35 & 2.60 & 0.00 & 0.05 & 31.41 \\
\hline Illite & 7.80 & 30.58 & 50.96 & 24.93 & 0.17 & 0.15 & 0.05 & 2.87 \\
\hline Hematite & 0.00 & 0.00 & 0.00 & 3.39 & 0.01 & 0.00 & 0.00 & 0.00 \\
\hline Feldspar & 5.17 & 0.00 & 4.46 & 4.71 & 3.01 & 0.12 & 0.02 & 4.53 \\
\hline Kaolinite & 22.32 & 0.00 & 21.97 & 0.00 & 4.26 & 0.38 & 0.37 & 0.00 \\
\hline Calcite & 0.00 & 0.00 & 7.00 & 0.00 & 0.00 & 0.00 & 0.00 & 0.00 \\
\hline Quartz & 0.00 & 0.00 & 0.00 & 0.00 & 0.00 & 0.00 & 0.0003 & 0.00 \\
\hline Gypsum & 0.00 & 0.00 & 0.56 & 0.00 & 0.00 & 0.00 & 0.00 & 0.00 \\
\hline Vermiculite & 0.00 & 0.00 & 0.00 & 0.00 & 3.00 & 0.00 & 0.00 & 0.00 \\
\hline Chlorite & 0.00 & 0.00 & 0.00 & 0.00 & 2.00 & 0.00 & 0.00 & 0.00 \\
\hline Goethite & 0.00 & 0.00 & 0.00 & 0.00 & 0.0006 & 0.00 & 0.00 & 0.00 \\
\hline Mica & 0.00 & 0.00 & 0.00 & 0.00 & 0.00 & 0.00 & 0.00 & 0.00 \\
\hline
\end{tabular}

for each chemical element is thus calculated as

$$
\left\{\begin{array}{l}
\mathrm{DF}_{\mathrm{Nso}}^{b}=\sum_{i=1}^{M}\left(\mathrm{DF}_{i}^{b} \cdot \%_{\mathrm{Ni}} \cdot \%_{\text {solubNi }}\right) \\
\mathrm{DF}_{\mathrm{Nin}}^{b}=\sum_{i=1}^{M}\left(\mathrm{DF}_{i}^{b} \cdot \%_{\mathrm{Ni}} \cdot\left(1 .-\%_{\text {solubNi }}\right)\right)
\end{array}\right.
$$

with $\mathrm{DF}_{N}^{b}$ the deposition flux of the chemical element $N$ (i.e. $\mathrm{Fe}, \mathrm{Ca}$, etc.) for its bin $b$. This flux is split between the soluble (so) and insoluble (in) parts. $\% \mathrm{Ni}$ is the percentage of chemical element $N$ in each mineral $M$ and $\%_{\text {solubNi }}$ the percentage of soluble fraction of chemical element $N$ in each mineral $M$.

\subsubsection{Boundary conditions}

Boundary conditions for mineral dust are calculated using a climatology calculated with the GOCART model (Ginoux et al., 2001). This climatology was provided by Mian Chin and Paul Ginoux for the CHIMERE validation and distribution to users. The data are freely available on the CHIMERE download website. The data represent a monthly global climatology simulation of mineral dust with a horizontal resolution of $2.5^{\circ} \times 2^{\circ}$ (Ginoux et al., 2001). The monthly mineral dust concentration fields are an average of the years 1987, 1988, 1989, 1990 and 1997 and divided into seven size bins, later reprojected in the CHIMERE aerosol bins. The use of this climatology in the case of this study has a major weakness: knowing that the data are for the usual mean mineral dust species. The question was thus to choose how to redistribute this mean species into all mineralogical species. To avoid errors, it was decided to add this contribution to the other species called DuOT. After some test cases, it was shown that the contribution of the boundary conditions was very low compared to the emissions calculated in the modelled domain. The impact of this hypothesis on the results was found to be negligible.

\section{Impact of the mineralogy on the total modelled mass}

This first section of results aims at compare two simulations performed with the WRF-CHIMERE models. The first one, called DUST, used the mineral dust modelling as presented in Menut et al. (2016), i.e. with only one mean species. The 

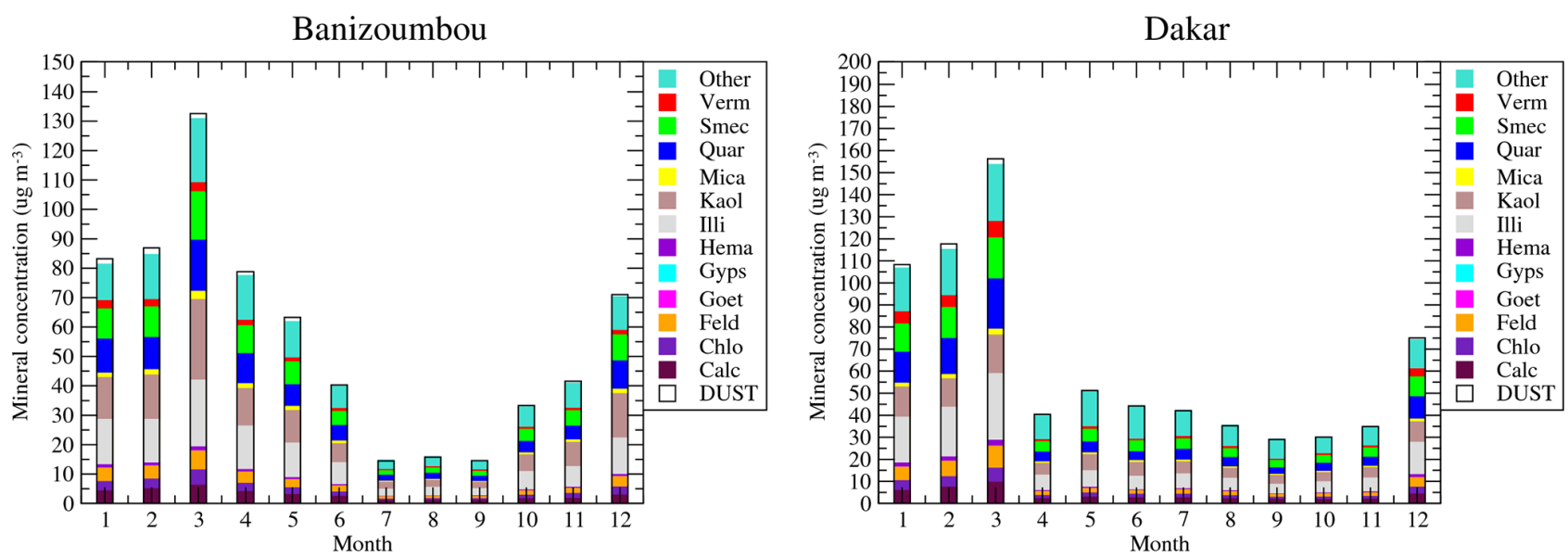

Lampedusa
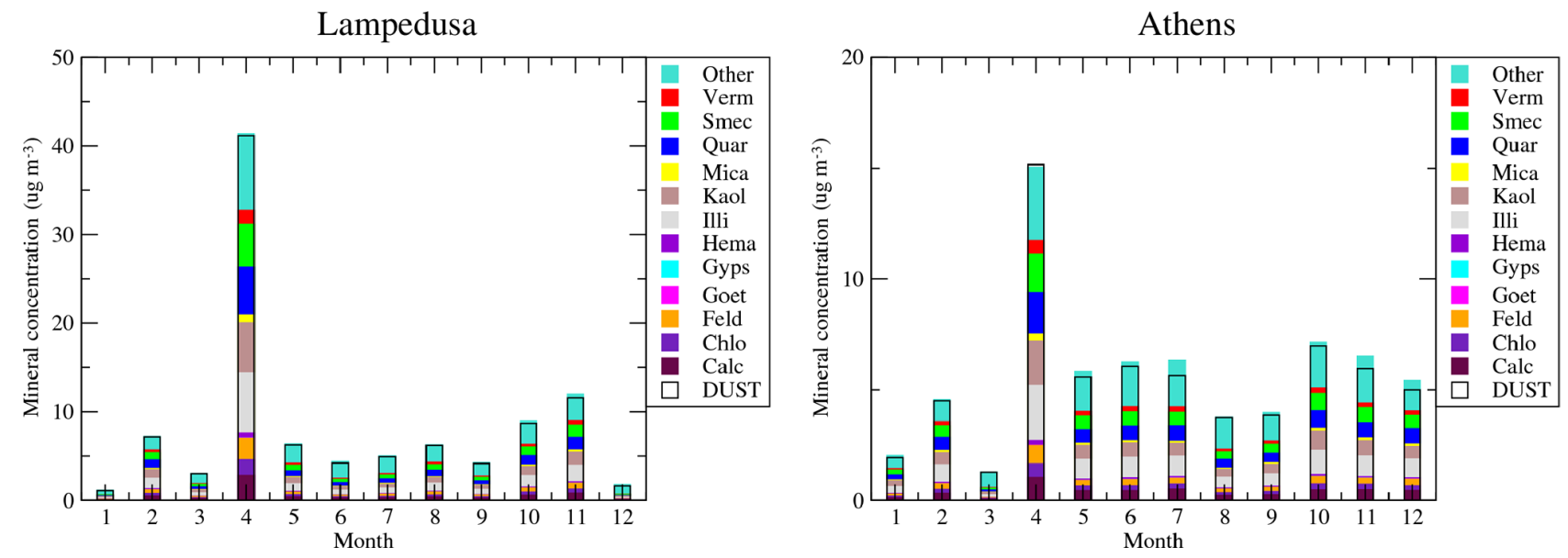

Figure 4. Monthly averaged modelled surface concentrations of the mean DUST species and all mineralogical species (micrograms per cubic metre).

second one, called MNRLO, used the model developments presented in this study, with different mineralogical species.

The surface concentrations of mineral dust are displayed in Fig. 4. Results are presented for the whole year 2012 and for the two simulations (DUST and MNRLO). As we have no direct surface measurements of mineral dust, only the model results are presented for intercomparison. Results are shown for four sites, representative of several locations in the model domain: Banizoumbou and Dakar are close to the mineral dust sources, Lampedusa is an island in the Mediterranean Sea and representative of concentrations after longrange transport, and Athens is located in Europe and in the north of the Mediterranean Sea and is also representative of long-range transport of African dust.

The 12 modelled species of MNRLO are represented as colour bars. The corresponding DUST concentration is presented as a white box, superimposed on these colours. The time series show that simulated concentrations reach a maximum in March and April over Africa. In Banizoumbou and Dakar, which are close to mineral dust sources, monthly mean surface concentrations may reach $160 \mu \mathrm{g} \mathrm{m}{ }^{-3}$. Over sites more remote from the sources, such as Lampedusa, the mean concentration is around $10 \mu \mathrm{g} \mathrm{m}^{-3}$, except in April, with the maximum reaching $40 \mu \mathrm{g} \mathrm{m}^{-3}$. The same peak is modelled in Athens, but with lower values: $5 \mu^{-3} \mathrm{~m}^{-3}$ on average during the year and $15 \mu \mathrm{g} \mathrm{m}^{-3}$ for the April peak.

The relative composition of dust, species per species, in Africa and Europe is close. It means that after emissions (in Africa), the transport and deposition affect all species in the same manner, even if their densities are different. The main compounds are smectite, quartz, kaolinite and illite. These results also show that the decomposition of the mineral dust into several species has no real impact on the final budget in mass: the sum of all individual mineral species concentrations of MNRLO is close to the DUST species. This is verified whatever the studied site, near or remote from sources.

In order to better quantify the changes in mass between DUST and MNRLO, the ratio of MNRLO/DUST is calculated for each month. Results are presented in Fig. 5 for the four sites presented above. The ratios vary a lot from month to month and are different for each site. But, globally, its variations are within an interval from 0.9 to 1.15 . It means 


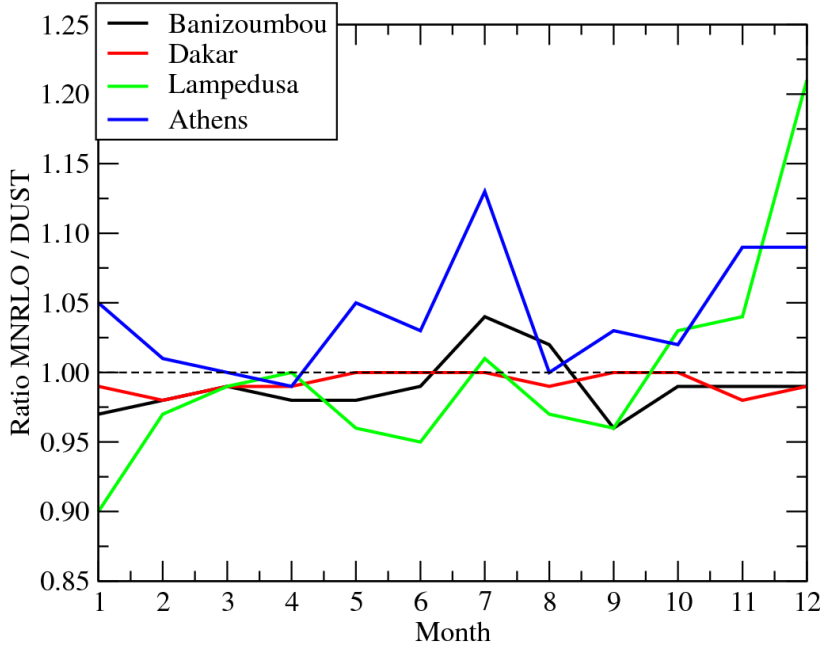

Figure 5. Surface concentrations ratios (ad. - dimensionless) between MNRLO and DUST and for four sites: Banizoumbou, Dakar, Lampedusa and Athens.

that whatever the location and the period of the year, the model explicitly resolves the mineralogical composition and induces a maximum change of $\approx \pm 15 \%$. One can also note that for April, when the largest mass is simulated, the ratio is close to 1 at the four sites: the differences are not linearly dependent on the concentration.

The only parameter affecting the total concentrations is aerosol density. This parameter directly affects dry deposition. The fact that we have a weak difference indicates that the deposition of the aggregated density of the individual mineral species (depending on their relative abundance) is close to the averaged density used for the species DUST alone.

\section{Model vs. observations}

In this section, results from the simulations are compared to observations. Mineral dust concentrations never being directly measured, comparison is achieved on variables linked to them. First, comparison is done with particulate matter surface concentrations (EMEP network), then secondly with AOD (AERONET photometers), and thirdly with nssCA ${ }^{2+}$ deposition fluxes (EMEP).

\subsection{Surface concentrations of $\mathrm{PM}_{2.5}$}

The comparison between surface measurements of $\mathrm{PM}_{2.5}$ and the model is presented in Table 4. The stations are located in western Europe and the composition of the particulate matter is a mix between anthropogenic, biogenic, mineral dust and biomass burning contributions (Menut et al., 2016). Results are presented as mean values over all stations
Table 4. Comparison of daily mean $\mathrm{PM}_{2.5}$ surface concentrations (micrograms per cubic metre) between EMEP observations and the CHIMERE model. Results are presented for the spatial correlation $R_{\mathrm{S}}$ between the mean observed and modelled values and the mean averaged values of temporal correlation, RMSE and bias.

\begin{tabular}{lrr}
\hline $\mathrm{PM}_{2.5}$ & DUST & MNRLO \\
\hline$R_{\mathrm{S}}$ & 0.38 & 0.39 \\
$\overline{R_{\mathrm{t}}}$ & 0.37 & 0.37 \\
RMSE & 3.13 & 3.12 \\
Bias & 6.23 & 6.19 \\
\hline
\end{tabular}

to have a integrated view of the differences between the two simulations.

The error statistics are in line with the range of what is currently modelled for $\mathrm{PM}_{2.5}$ in areas with multiple sources such as western Europe. But the most striking point in this table is how similar the two simulations are. The spatial correlation, $R_{\mathrm{S}}$, is 0.38 and 0.39 for DUST and MNRLO, respectively. The score is low and there is no clear improvement using the speciation of the mineralogy. The same is true for the other statistical values: the averaged temporal correlation, $\overline{R_{\mathrm{t}}}$, is the same. Only the bias is slightly lower for MNRLO with a value of 6.19 (to be compare to 6.23 for DUST), but the difference between the simulations is feeble and these differences cannot be regarded as significant.

The statistical values are not satisfactory: to better understand them, time series are presented, as examples, in Fig. 6. Results are presented for Diabla Gora and Harwell. For these two sites, concentrations are maximal in winter. We can see the large temporal variability of measured and modelled values. Although the model does not always catch the day-today variability, the main tendencies and the background values are correctly captured. In terms of surface concentrations, there is no significant difference between DUST and MNRLO.

\subsection{Surface concentrations of individual aerosols}

More detailed statistical scores are presented in Table 5. The comparison is made between modelled and measured (EMEP network) daily averaged surface concentrations. For each species, the number of daily data varies from 17 to 83 over Europe. The statistics are expressed with the root mean squared error (RMSE), the correlation $R$, and the mean fractional bias and error, MFB and MFE, respectively (see, among many others, Chang and Hanna, 2004; Boylan and Russell, 2006, for the definitions of these metrics).

The analysed species are calcium $(\mathrm{Ca}$, micrograms per cubic metre), sulfate $\left(\mathrm{SO}_{4}^{2-}, \mu \mathrm{gS} \mathrm{m}{ }^{-3}\right)$, nitrate $\left(\mathrm{NO}_{3}^{-}\right.$, $\left.\mu \mathrm{g} \mathrm{N} \mathrm{m}{ }^{-3}\right)$, nitrogen oxides $\left(\mathrm{NO}_{2}\right.$, micrograms per cubic metre). For the simulation without mineralogy, the calcium is estimated as $\alpha$ DUST with $\alpha=0.06$. For inorganic species $\left(\mathrm{SO}_{4}^{2-}, \mathrm{NO}_{3}^{-}\right)$and $\mathrm{NO}_{2}$, the statistical scores have a satisfac- 
Table 5. Daily mean surface concentrations and wet-deposition fluxes of gas and aerosols. Comparisons are presented between EMEP measurements and CHIMERE modelling. Aerosol species are mineral dust, calcium $\left(\mathrm{Ca}^{2+}\right.$, micrograms per cubic metre), sulfate $\left(\mathrm{SO}_{4}^{2-}\right.$ $\left.\mu \mathrm{g} \mathrm{S} \mathrm{m}{ }^{-3}\right)$, nitrate $\left(\mathrm{NO}_{3}^{-}, \mu \mathrm{g} \mathrm{N} \mathrm{m}^{-3}\right)$, and nitrogen oxides $\left(\mathrm{NO}_{2}\right.$, micrograms per cubic metre). In the case of DUST, the calcium concentration is estimated by using the surface concentrations of mineral dust multiplied by a factor $\alpha=0.06$. In the case of MNRLO, the calcium and magnesium ( $\mathrm{Mg}$, micrograms per cubic metre) is explicitly modelled as well as their respective wet deposition - WCa and WMg $\left(\mu \mathrm{g} \mathrm{m}^{-2} \mathrm{~d}^{-1}\right)$.

\begin{tabular}{llrrrrrr}
\hline Species & Simulation & $\overline{c_{\text {mod }}}$ & $\overline{c_{\text {obs }}}$ & RMSE & $R$ & MFB & MFE \\
\hline$\alpha$ DUST & DUST & 0.09 & 0.18 & 0.30 & 0.30 & -0.97 & 1.15 \\
$\mathrm{Ca}^{2+}$ & MNRLO & 0.06 & 0.18 & 0.30 & 0.26 & -1.29 & 1.39 \\
\hline $\mathrm{WCa}$ & DUST & 0.73 & 0.91 & 7.04 & 0.07 & -0.39 & 0.45 \\
& MNRLO & 0.44 & 0.91 & 6.34 & 0.08 & -0.51 & 0.54 \\
\hline $\mathrm{SO}_{4}^{2-}$ & DUST & 1.52 & 1.89 & 1.62 & 0.40 & -0.14 & 0.53 \\
& MNRLO & 1.52 & 1.89 & 1.62 & 0.40 & -0.14 & 0.53 \\
\hline $\mathrm{NO}_{3}^{-}$ & DUST & 3.94 & 2.22 & 4.13 & 0.55 & 0.28 & 0.75 \\
& MNRLO & 3.95 & 2.22 & 4.13 & 0.55 & 0.28 & 0.75 \\
\hline $\mathrm{NO}_{2}$ & DUST & 7.61 & 6.82 & 7.76 & 0.40 & 0.15 & 0.60 \\
& MNRLO & 7.60 & 6.82 & 7.76 & 0.40 & 0.15 & 0.60 \\
\hline $\mathrm{Mg}$ & MNRLO & 0.07 & 0.12 & 0.15 & 0.50 & -0.68 & 0.90 \\
$\mathrm{WMg}^{2}$ & MNRLO & 0.15 & 0.59 & 3.76 & 0.02 & -0.49 & 0.53 \\
\hline
\end{tabular}

tory correlation from 0.40 to 0.55 over the period and the domain. The MFB shows an overestimation of $\mathrm{NO}_{3}^{-}$and $\mathrm{NO}_{2}$ but an underestimation of $\mathrm{SO}_{4}^{2-}$. For calcium, the use of the mineralogy does not change the results significantly: the correlation is 0.3 without mineralogy and 0.26 with mineralogy, and the bias is increased with mineralogy. The differences between the two simulations are not significant, and the statistical scores are not improved with the explicit calculation of the mineralogy.

\subsection{Optical depth}

We now present the comparison of aerosol optical depth results with AERONET measurements. We want to quantify whether or not the different refractive indices of the individual minerals have an impact on AOD calculation.

First, maps are presented in Fig. 7. Panel a displays the mean averaged value of AOD for April 2012 (when the largest surface concentrations were modelled) and for the simulation DUST. Two large areas of high AOD values are modelled in Africa where maximum values reached are larger than 2. The locations correspond to active mineral dust sources. The bottom panel presents the difference AOD(DUST)-AOD(MNRLO). The largest differences appear where there are maximum absolute values of AOD in the Sahara and Sahel. Aside from this area, the differences are close to zero and could be regarded as non-significant. These results show that the use of speciated dust tends to increase the AOD, but the impact does not affect long-rangetransported dust.
Table 6. Comparison between observations (AERONET) and model (CHIMERE) for the daily mean aerosol optical depth (AOD). Results are presented for the spatial correlation $R_{\mathrm{S}}$ between the mean observed and modelled values and the mean averaged values of temporal correlation, RMSE and bias.

\begin{tabular}{lrr}
\hline AOD & DUST & MNRLO \\
\hline$R_{\mathrm{S}}$ & 0.95 & 0.94 \\
$R_{\mathrm{t}}$ & 0.51 & 0.50 \\
RMSE & 3.58 & 3.49 \\
Bias & 0.09 & 0.07 \\
\hline
\end{tabular}

Statistical scores are calculated over 32 AERONET stations and are presented in Table 6. As for previous results, differences between the two simulations are small. In terms of yearly mean AOD value, DUST provides higher values than MNRLO, as displayed with Fig. 7. There is a positive bias of the simulations compared to the measurements; i.e. the two simulations produce larger AOD than the measurements.

The bias is lower for MINERAL than for DUST, but the differences are not significant (0.07 vs. 0.09). Only the RMSE is improved between the two simulations (3.58 for DUST and 3.49 for MNRLO). Finally, the speciation of the dust does not bring a significant improvement on the AOD modelling. 

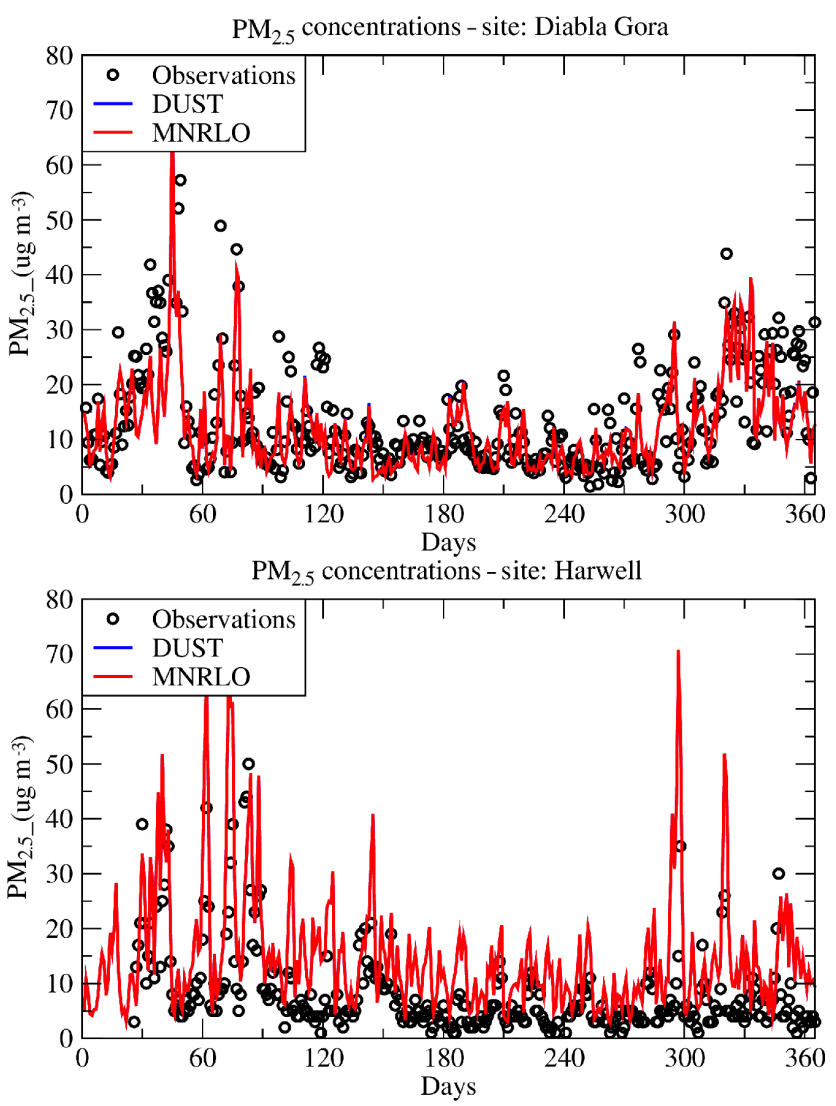

Figure 6. Daily averaged surface concentrations of $\mathrm{PM}_{2.5}$ with the EMEP measurements and the two CHIMERE simulations, DUST and MNRLO.

\section{Modelling of calcium}

In this section, modelled calcium contributed to by mineral dust is evaluated through a comparison to measurements. Thus, only the simulation MNRLO can be compared to measurements.

\subsection{Deposition fluxes}

Simulated monthly mean wet-deposition fluxes of nssCA ${ }^{2+}$ and the cumulative precipitations are compared with EMEP measurements in Fig. 8. Results are shown for nine European sites located far away from Saharan dust sources. Symbols are used to represent wet deposition, whereas solid lines indicate the values for precipitations.

The precipitations are well captured by the model. The absolute values of precipitations are close between model and measurements. For each site, the seasonal cycle is also well reproduced with a peak in June at Vysokoe and Schmücke, and peaks in July and October at Zingst, amongst other sites.

In contrast, the simulated deposition fluxes underestimate the observed fluxes significantly. While measurements never approach $0 \mathrm{mg} \mathrm{m}^{-2}$, the deposition fluxes simulated by the
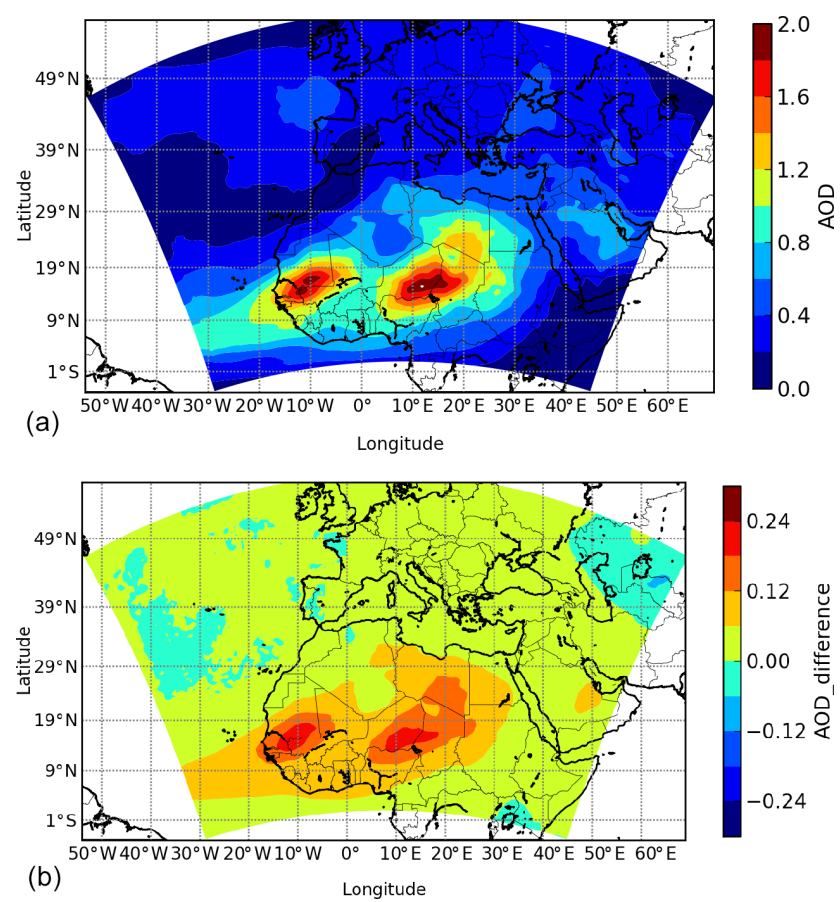

Figure 7. Monthly averaged aerosol optical depth for April 2012 and over the whole modelled domain. (a) AOD absolute values are presented for the simulation DUST. (b) The map of difference represents the calculation of AOD(DUST)-AOD(MNRLO).

model are more sporadic and close to 0 for several months. The measurements exhibit summer maxima, but they are always captured by the model; at some sites, depositions fluxes are simulated in April (Ispra) or in September and October (Brotjacklriegel and Westerland). The capability of a model to simulate the dust cycle contains many processes and, thus, many possible errors. Here, the precipitation is correctly represented by the model. It means that the underestimation of modelled wet-deposition fluxes compared to the measurements is probably due to other processes than a misrepresentation of the precipitation. This could be the altitude of the precipitating clouds, the trajectory of dust plumes (missing a station or not), the efficiency of the parameterised scavenging, possible errors in dust size distribution and too small a simulated fraction of $\mathrm{nssCa}^{2+}$, among other possibilities.

Statistical results are presented in Table 7 for the 35 EMEP stations available in 2012. They show a large variability between the stations. The modelled values are also clearly underestimated. Independently of this underestimation, the temporal correlation is not good and does not exceed 0.42 (at the DE0044R station).

Since dust plumes are very spatially extensive, there is usually a bias between model and measurements for groups of stations located beneath these plumes. This is not the case here, since there are highly variable biases for nearby stations. The origin of the bias is therefore not due to a 'large scale' error: it is therefore probably not a transport problem. 

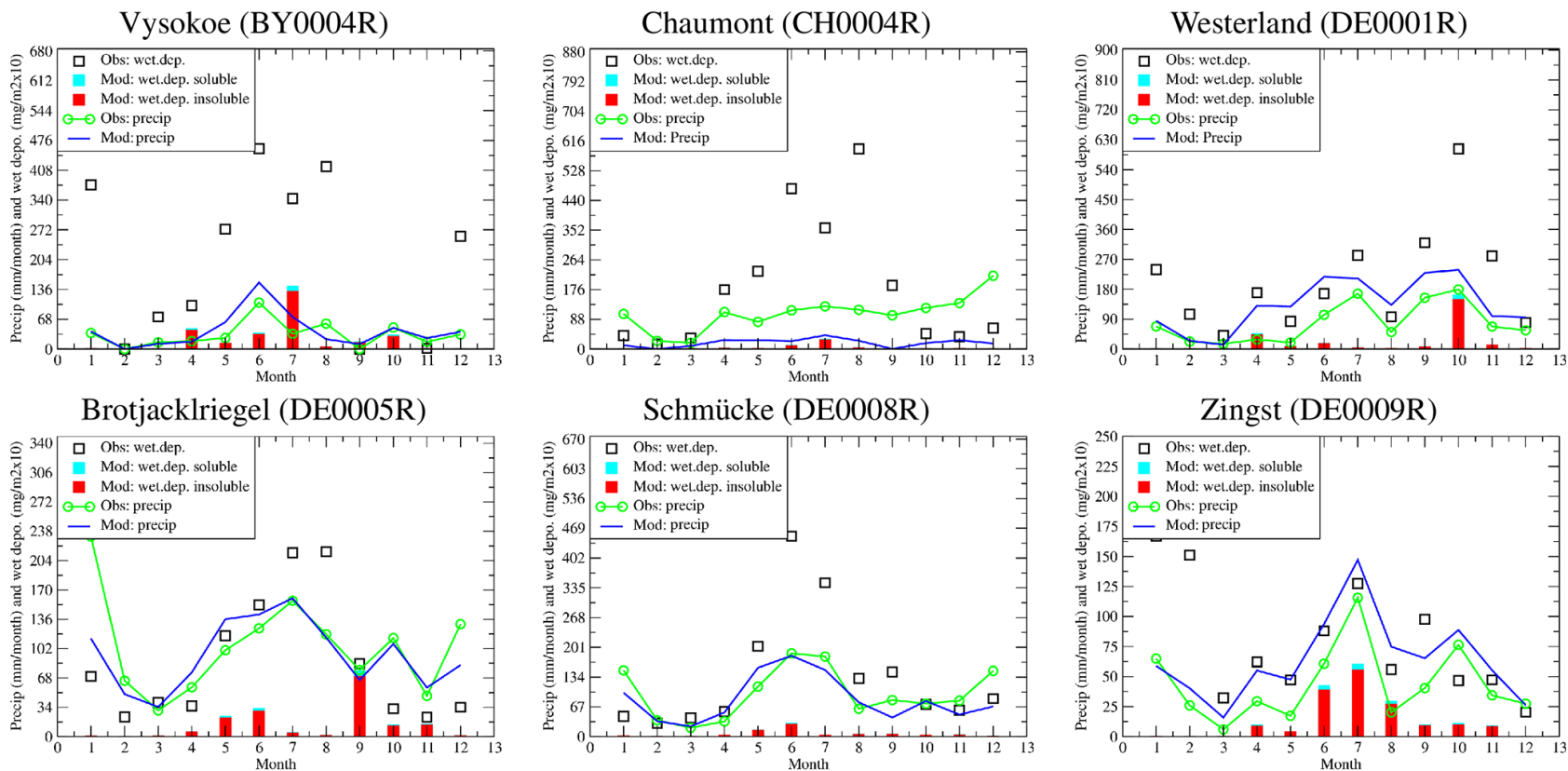

Mahón (ES0006R)
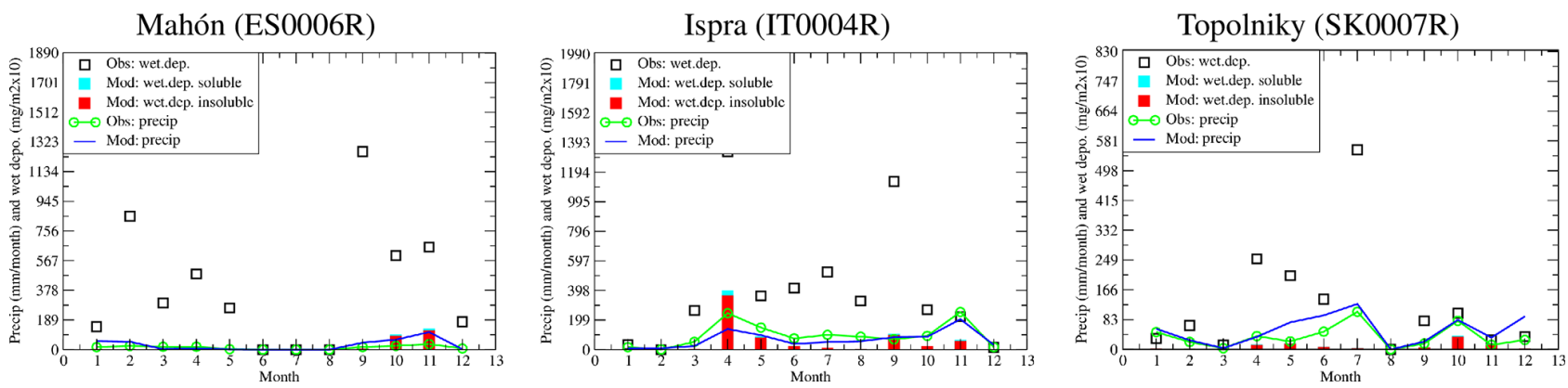

Figure 8. Time series of monthly precipitation rates (millimetres per month) and $\mathrm{nssCa}^{2+}$ wet-deposition fluxes $\left(\mathrm{mg}^{2}\left(\mathrm{~m}^{-2}\right) 10\right)$. The bars represent the monthly deposition fluxes of $\mathrm{Ca}^{2+}$ : soluble in blue and insoluble in red. The blue line represents the simulated monthly cumulated precipitations. The measurements are represented with symbols. Results are presented for the whole year of 2012 and observations are accumulated monthly from weekly measurements.

But it may be a precipitation problem, which is often a phenomenon of greater spatial variability on a small scale.

\subsection{The $\mathrm{nsSCA}^{2+} /$ dust ratio}

The ratio between $\mathrm{nssCA}^{2+}$ and total mineral dust concentration is often used to convert measurements of calcium into a total mass of dust. It is used to compare observations to model outputs. Usually, previous authors present ratios of dust $/ \mathrm{nssCA}^{2+}$. But for low values $\mathrm{nssCA}^{2+}$, this ratio may have important values difficult to interpret. Since the goal is to quantify the relative amount of $n \mathrm{CA}^{2+}$ in a total mass concentration of mineral dust, it seems more logical to express the results as a ratio between 0 and 1 with $\mathrm{nssCA}^{2+} /$ dust.

The explicit modelling of dust mineralogy and chemical composition allows us to plot a map of this ratio (Fig. 9). The values represented in the figure consist of an average of all values simulated during the year 2012. Values are in the range between 0 and 0.05 over the whole domain. Maxima are modelled in Africa and the eastern part of the modelled domain. Over western Europe, the values are lower and between 0 and 0.03. Over the Mediterranean Sea, the ratio is relatively homogeneous and with values close to 0.035 . Considering this map, it seems clear this is not realistic to use a single and constant value to convert $\mathrm{nssCA}^{2+}$ mass measurements into mineral dust.

In order to compare the map of results to previously published values, we report in Table 8 the values found in the literature and the calculation made in this study. The results with the model are close to the values found by Lequy et al. (2013), but only for the Breuil site. But if we consider there is a strong model bias (as shown in Fig. 8) and only for $\mathrm{nssCA}^{2+}$ and not the complete mass of mineral dust, then these values should be closer than the ones found by Lequy et al. (2013) (Hesse site) and Putaud et al. (2004). 
Table 7. Comparisons between observations (EMEP) and model (CHIMERE) for the weekly mean deposition fluxes of $n^{2} \mathrm{CA}^{2+}$ (milligrams per square metre). Results are presented for the whole year 2012 and for the temporal correlation $\left(R_{\mathrm{t}}\right)$, the root mean squared error (RMSE) and the bias (model minus observations). The last line "average" represents the spatial correlation $R_{\mathrm{S}}$ between the mean observed and modelled values and the mean averaged values of temporal correlation, RMSE and bias.

\begin{tabular}{l|rr|rrr}
\hline \multicolumn{6}{l}{ Weekly mean deposition fluxes of nssCA } \\
\end{tabular}

\section{Conclusions}

The present study consists of the implementation of the mineralogical speciation of dust in the CHIMERE chemistrytransport model. Several databases were implemented and 12 minerals are explicitly treated in ways of emission, transport and deposition in contrast to a single one with a classic approach. A new and simple function is also introduced to

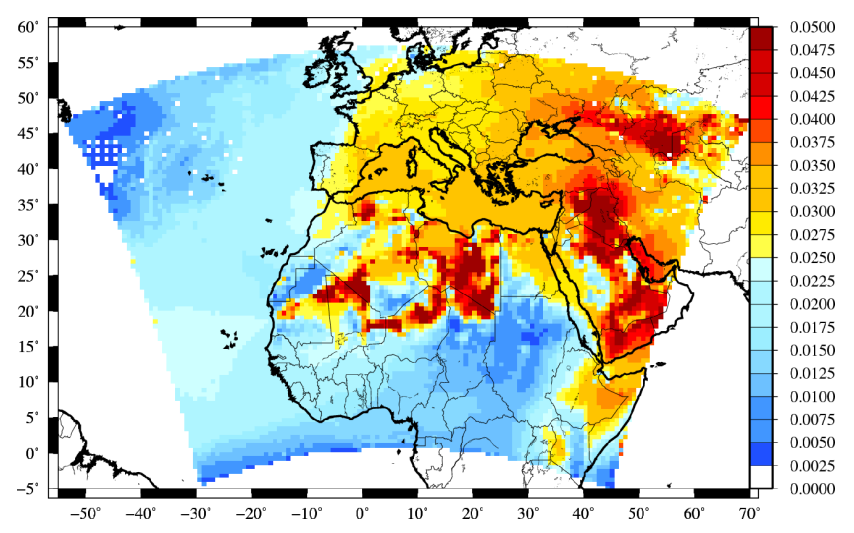

Figure 9. Modelled ratio of nssCA ${ }^{2+}$ on total mineral dust concentrations. The ratio corresponds to the yearly averaged value.

Table 8. Values of the ratio $\mathrm{nssCA}^{2+} /$ dust found in the literature and modelled in this study. The values correspond to the inverted value of what is generally calculated.

\begin{tabular}{llr}
\hline Reference & Region & $\mathrm{nssCA}^{2+} /$ dust \\
\hline Putaud et al. (2004) & western Europe & 0.22 \\
Lequy et al. (2013) & Breuil, France & 0.03 \\
Lequy et al. (2013) & Hesse, France & 0.2 \\
This study & Africa & 0.05 (max) \\
This study & western Europe & 0.03 (max) \\
\hline
\end{tabular}

correct the effect of wet sieving and partition accurately the relative part between the silt and the clay fractions. Several motivations justify the need to have dust mineralogical speciation: to better follow the emissions depending on soil type, to better capture the aerosol radiative effect, to better inform biogeochemical models and to improve the comparison of deposition fluxes to the available measurements.

We infer that surface concentrations of particulate matter, considered here as $\mathrm{PM}_{2.5}$ surface concentrations, are close between DUST and MNRLO. On the one hand, we would expect this result since the total mass of mineral dust emissions is the same for DUST and MNRLO. On the other hand it can be surprising: since the densities of individual mineralogical species depart from the average density used for the mean DUST species, one might have expected to see larger differences during the transport due to differential particle settling between the different minerals. The mean density used for the bulk species DUST is thus well representative of the whole set of mineralogical species. Concerning aerosol optical depth, this study confirmed the statistical scores when comparing simulated optical depths to retrieved ones, but no particular improvements were obtained by using MNRLO in place of the single DUST. Despite the large variability of refractive indices, the calculation based on 12 species did not improved the AOD calculation. Once again, it means that 
the use of the mean averaged refractive indices seems to be a good proxy of dust aggregates.

The modelled calcium part of the mineral dust was compared to EMEP measurements. Results showed large negative biases. As a major part of mineral dust comes from north Africa, one could have expected the error to increase with the distance from the sources, but this was not the case. For $\mathrm{nssCa}^{2+}$ wet-deposition fluxes, the modelled values underestimate the measurements significantly. On the other hand, precipitation is reasonably modelled, showing that the problem could come from the representation of the dust plume itself or from additional sources not accounted for but not from the meteorology. Finally, the ratio $\mathrm{nsCa}^{2+} /$ dust is estimated. Often used as proxy for biogeochemical studies, the implementation of the mineralogy enables us to calculate it explicitly. A yearly averaged map is proposed, and for locations where values were proposed in the literature, we showed that our results are fairly close to the observed ones.

These results showed that the implementation of the mineralogical speciation in the model provides additional information for use with biogeochemical modelling and does not change the results significantly in terms of AOD or surface concentrations. A step forward could be to add the Fe anthropogenic emissions to the model and then to have realistic $\mathrm{Fe}$ concentrations and deposited fluxes to make comparisons to measurements, as done for example in Ito et al. (2019). 


\section{Appendix A: Coordinates of the measurement sites}

Coordinates of the measurement sites are presented in this Appendix.

Table A1. List of the AERONET sites for the AOD measurements.

\begin{tabular}{lrr}
\hline AERONET stations & $\begin{array}{r}\text { Longitude } \\
\text { Name }\end{array}$ & $\begin{array}{r}\text { Latitude } \\
\left({ }^{\circ}\right)\end{array}$ \\
\hline Athens & 23.77 & 37.98 \\
Banizoumbou & 2.66 & 13.54 \\
Barcelona & 2.11 & 41.38 \\
Bastia & 9.44 & 42.69 \\
Bodele & 18.55 & 16.88 \\
Bondoukoui & -3.75 & 11.85 \\
Brussels & 4.35 & 50.78 \\
Cinzana & -5.93 & 13.27 \\
Cabauw & 4.92 & 51.97 \\
CapoVerde & -22.93 & 16.73 \\
Chilbolton & -1.43 & 51.14 \\
Dakar & -16.95 & 14.39 \\
Dahkla & -15.95 & 23.72 \\
Evora & -7.91 & 38.56 \\
ForthCrete & 25.27 & 35.31 \\
Granada & -3.60 & 37.16 \\
Ilorin & 4.34 & 8.320 \\
Izana & -16.49 & 28.31 \\
Katibougou & -7.53 & 12.92 \\
Karlsruhe & 8.42 & 49.09 \\
LaLaguna & -16.32 & 28.48 \\
Lampedusa & 12.63 & 35.51 \\
LecceUniversity & 18.11 & 40.33 \\
Leipzig & 12.43 & 51.35 \\
Lille & 3.14 & 50.61 \\
Palaiseau & 2.20 & 48.70 \\
RomeTorVergata & 12.64 & 41.84 \\
Saada & -8 & 31 \\
Tamanrasset & 5.53 & 22.79 \\
Tenerife & -16.24 & 28.47 \\
Villefranche & 7.32 & 43.68 \\
ZinderAirport & 8.98 & 13.75 \\
\hline
\end{tabular}

Table A2. List of the EMEP sites for the surface concentrations measurements.

\begin{tabular}{|c|c|c|c|}
\hline \multicolumn{2}{|c|}{ EMEP stations } & \multirow{2}{*}{$\begin{array}{r}\text { Longitude } \\
\left({ }^{\circ}\right)\end{array}$} & \multirow{2}{*}{$\begin{array}{r}\text { Latitude } \\
\qquad\left(^{\circ}\right)\end{array}$} \\
\hline Code & Name & & \\
\hline BY0004R & Vysokoe & 23.43 & 52.33 \\
\hline $\mathrm{CH} 0002 \mathrm{R}$ & Payerne & 6.94 & 46.81 \\
\hline $\mathrm{CH} 0004 \mathrm{R}$ & Chaumont & 6.97 & 47.04 \\
\hline CH0005R & Rigi & 8.46 & 47.06 \\
\hline CZ0001R & Svratouch & 16.05 & 49.73 \\
\hline CZ0003R & Kosetice & 15.08 & 49.58 \\
\hline DE0001R & Westerland & 8.30 & 54.92 \\
\hline DE0004R & Deuselbach & 7.05 & 49.76 \\
\hline DE0005R & Brotjacklriegel & 13.21 & 48.81 \\
\hline DE0008R & Schmücke & 10.76 & 50.65 \\
\hline DE0009R & Zingst & 12.73 & 54.43 \\
\hline DE0044R & Melpitz & 12.93 & 51.53 \\
\hline ES0001R & San Pablo & -4.34 & 39.54 \\
\hline ES0005R & Noya & -8.92 & 42.72 \\
\hline ES0006R & Mahón & 4.31 & 39.86 \\
\hline ES0007R & Viznar & -3.53 & 37.23 \\
\hline ES0008R & Niembro & -4.85 & 43.44 \\
\hline ES0009R & Campisabalos & -3.14 & 41.28 \\
\hline ES0017R & Donana & -6.33 & 37.03 \\
\hline GB0036R & Harwell & -1.31 & 51.57 \\
\hline GB0048R & Auchencorth & -3.24 & 55.79 \\
\hline HR0002R & Puntijarka & 15.96 & 45.9 \\
\hline HR0004R & Zavizan & 14.98 & 44.81 \\
\hline HU0002R & Kpuszta & 19.58 & 46.96 \\
\hline IT0004R & Ispra & 8.63 & 45.8 \\
\hline LT0015R & Preila & 21.06 & 55.35 \\
\hline ME0008R & Zabljak & 19.13 & 43.15 \\
\hline PL0002R & Jarczew & 21.98 & 51.81 \\
\hline PL0003R & Sniezka & 15.73 & 50.73 \\
\hline PL0004R & Leba & 17.53 & 54.75 \\
\hline SI0008R & Iskrba & 14.86 & 45.56 \\
\hline SK0002R & Chopok & 19.58 & 48.93 \\
\hline SK0004R & Stara Lesna & 20.28 & 49.15 \\
\hline SK0006R & Starina & 22.26 & 49.05 \\
\hline SK0007R & Topolniky & 17.86 & 47.96 \\
\hline
\end{tabular}




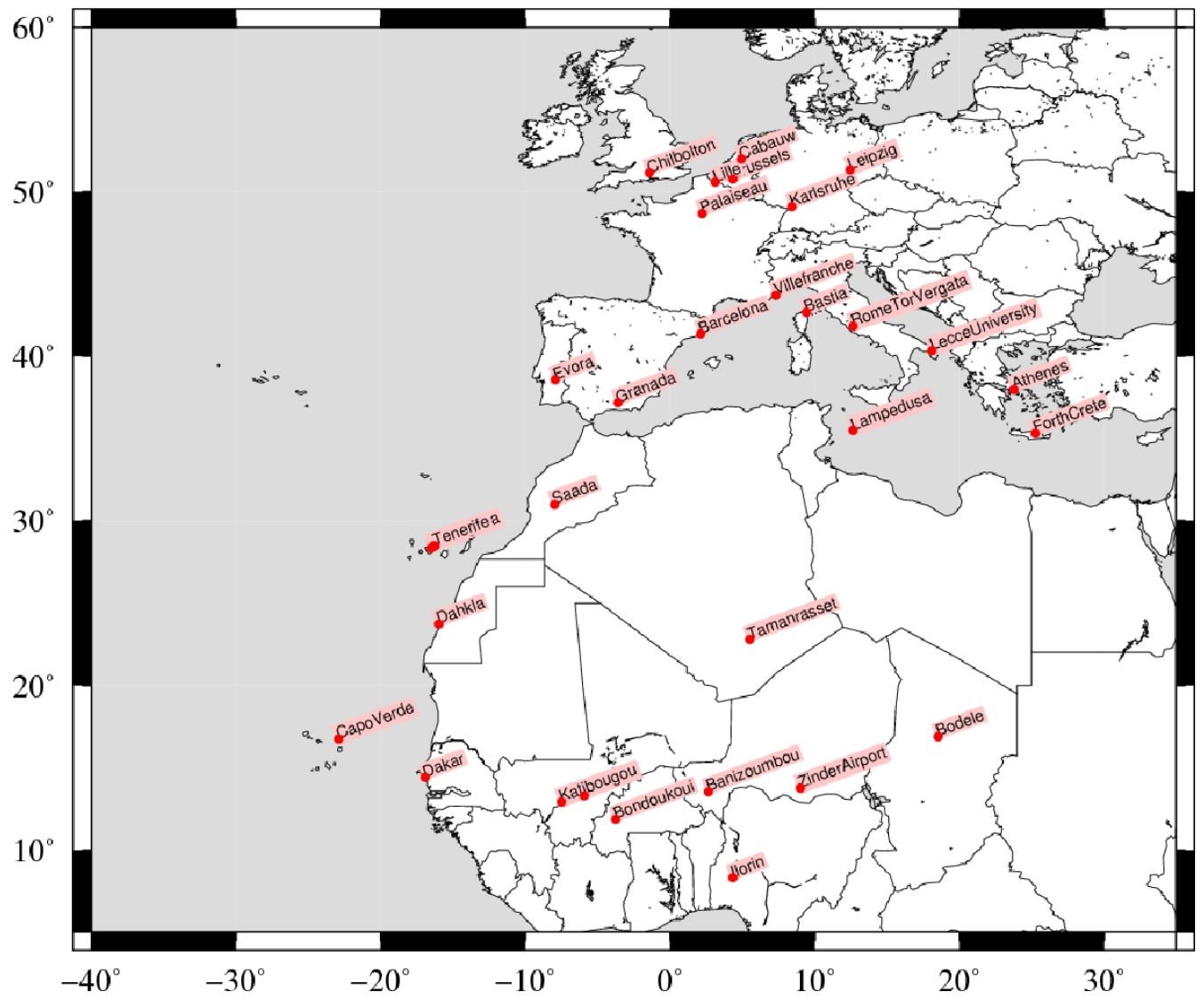

Figure A1. Maps of AERONET sites for the AOD measurements.

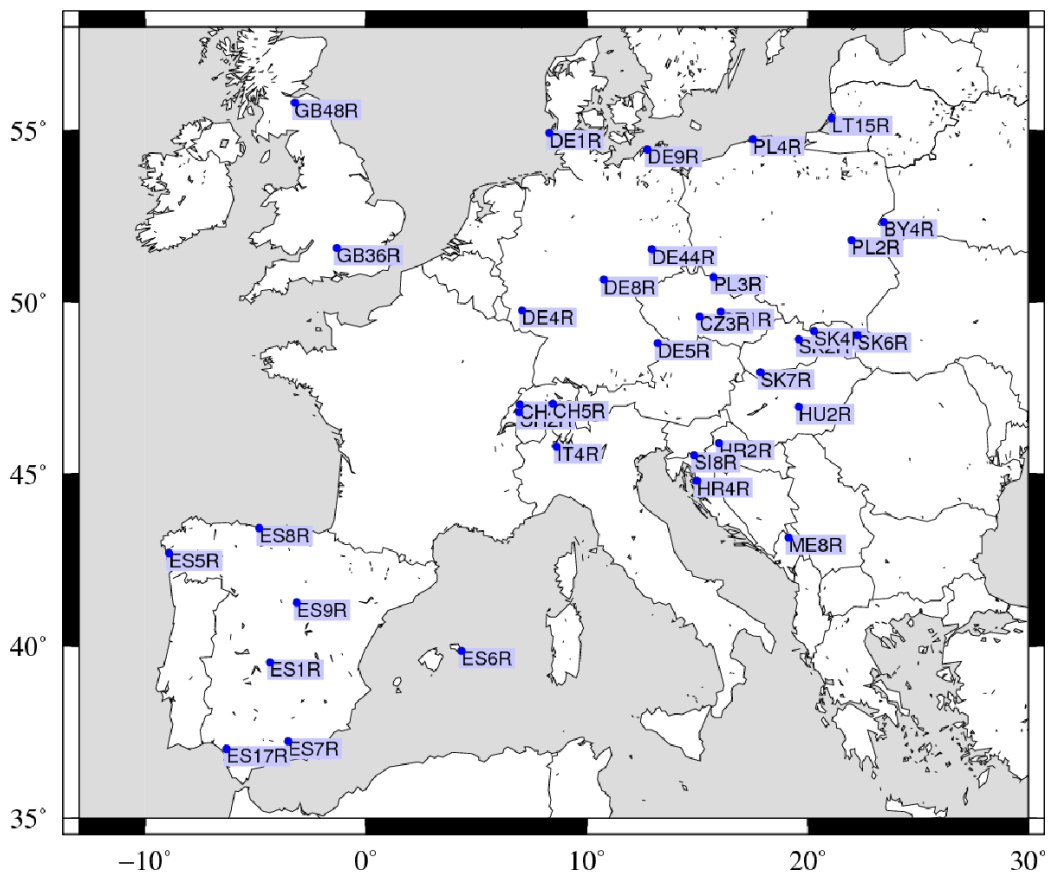

Figure A2. Maps of EMEP sites for the $\mathrm{PM}_{2.5}$ and calcium measurements. 
Data availability. The model version is available upon request to the first author.

Author contributions. LM and GS developed the code in the CHIMERE model, designed the experiments, performed the simulations, produced figures and tables, and wrote the paper. BB and FC reviewed and corrected the code and the paper, EJ and YB provided the model surface databases, essential for the calculations and primarily developed for the LMDz-INCA model, and KD updated the information necessary in the tables of the mineral composition and elemental solubility. All co-authors contributed to the final version of the paper.

Competing interests. The authors declare that they have no conflict of interest.

Acknowledgements. We acknowledge Jan P. Perlwitz for his very important help to find all information about the refractive index and densities of the mineralogical species. The EBAS database has largely been funded by the UN-ECE CLRTAP (EMEP), AMAP and through NILU internal resources. Specific developments have been possible due to projects like EUSAAR (EU-FP5) (EBAS web interface), EBAS-Online (Norwegian Research Council INFRA) (upgrading of database platform) and HTAP (European Commission DG-ENV) (import and export routines to build a secondary repository in support of http://www.htap.org, last access: 29 November 2019). Many specific projects have supported development of data and metadata reporting schemes in dialogue with data providers (EU) (CREATE, ACTRIS and others).

Review statement. This paper was edited by Samuel Remy and reviewed by two anonymous referees.

\section{References}

Alfaro, S. C. and Gomes, L.: Modeling mineral aerosol production by wind erosion: Emission intensities and aerosol size distribution in source areas, J. Geophys. Res., 106, 18075-18084, 2001.

Balkanski, Y., Schulz, M., Claquin, T., and Guibert, S.: Reevaluation of Mineral aerosol radiative forcings suggests a better agreement with satellite and AERONET data, Atmos. Chem. Phys., 7, 81-95, https://doi.org/10.5194/acp-7-81-2007, 2007.

Bedidi, A. and Cervelle, B.: Light scattering by spherical particles with hematite and goethitelike optical properties: Effect of water impregnation, J. Geophys. Res.-Sol. Ea., 98, 11941-11952, https://doi.org/10.1029/93JB00188, 1993.

Beegum, S., Gherboudj, I., Chaouch, N., Couvidat, F., Menut, L., and Ghedira, H.: Simulating Aerosols over Arabian Peninsula with CHIMERE: Sensitivity to soil, surface parameters and anthropogenic emission inventories, Atmos. Environ., 128, 185197, https://doi.org/10.1016/j.atmosenv.2016.01.010, 2016.

Bessagnet, B., Menut, L., Aymoz, G., Chepfer, H., and Vautard, R.: Modelling dust emissions and transport within Europe: the
Ukraine March 2007 event, J. Geophys. Res., 113, D15202, https://doi.org/10.1029/2007JD009541, 2008.

Bian, H. and Prather, M.: Fast-J2: accurate simulation of stratospheric photolysis in global chemical models, J. Atmos. Chem., 41, 281-296, 2002.

Boylan, J. W. and Russell, A. G.: PM and light extinction model performance metrics, goals, and criteria for threedimensional air quality models, Atmos. Environ., 40, 49464959, https://doi.org/10.1016/j.atmosenv.2005.09.087, 2006.

Chang, J. and Hanna, S.: Air quality model performance evaluation, Meteorol. Atmos. Phys., 87, 167-196, https://doi.org/10.1007/s00703-003-0070-7, 2004.

Chen, F. and Dudhia, J.: Coupling an advanced land surfacehydrology model with the Penn State-NCAR MM5 modeling system. Part I: Model implementation and sensitivity, Mon. Weather Rev., 129, 569-585, 2001.

Couvidat, F., Bessagnet, B., Garcia-Vivanco, M., Real, E., Menut, L., and Colette, A.: Development of an inorganic and organic aerosol model (CHIMERE 2017 $\beta$ v1.0): seasonal and spatial evaluation over Europe, Geosci. Model Dev., 11, 165-194, https://doi.org/10.5194/gmd-11-165-2018, 2018.

Davidson, C., Miller, J., and Pleskow, M.: The influence of surface structure on predicted particle air deposition to natural grass canopies, Water Air Soil Poll., 18, 25-44, 1982.

Desboeufs, K., Bon Nguyen, E., Chevaillier, S., Triquet, S., and Dulac, F.: Fluxes and sources of nutrient and trace metal atmospheric deposition in the northwestern Mediterranean, Atmos. Chem. Phys., 18, 14477-14492, https://doi.org/10.5194/acp-1814477-2018, 2018.

Engelstaedter, S., Tegen, I., and Washington, R.: North African dust emissions and transport, Earth-Sci. Rev., 79, 73-100, https://doi.org/10.1016/j.earscirev.2006.06.004, 2006.

$\mathrm{Fu}$, Y., Desboeufs, K., Vincent, J., Bon Nguyen, E., Laurent, B., Losno, R., and Dulac, F.: Estimating chemical composition of atmospheric deposition fluxes from mineral insoluble particles deposition collected in the western Mediterranean region, Atmos. Meas. Tech., 10, 4389-4401, https://doi.org/10.5194/amt10-4389-2017, 2017.

Giglio, L., Randerson, J. T., van der Werf, G. R., Kasibhatla, P. S., Collatz, G. J., Morton, D. C., and DeFries, R. S.: Assessing variability and long-term trends in burned area by merging multiple satellite fire products, Biogeosciences, 7, 1171-1186, https://doi.org/10.5194/bg-7-1171-2010, 2010.

Ginoux, P., Chin, M., Tegen, I., Prospero, J. M., Holben, B., Dubovik, O., and Lin, S. J.: Sources and distributions of dust aerosols simulated with the GOCART model, J. Geophys. Res., 106, 20255-20273, 2001.

Giorgi, F.: A particle dry deposition scheme for use in tracer transport models, J. Geophys. Res., 91, 9794-9806, 1986.

Grell, G. and Dévényi, D.: A generalized approach to parameterizing convection combining ensemble and data assimilation techniques, Geophys. Res. Lett., 29, 38-1-38-4, https://doi.org/10.1029/2002GL015311, 2002.

Guieu, C., Loye-Pilot, M., Benyahya, L., and Dufour, A.: Spatial variability of atmospheric fluxes of metals (Al, $\mathrm{Fe}, \mathrm{Cd}, \mathrm{Zn}$ and $\mathrm{Pb}$ ) and phosphorus over the whole Mediterranean from a one-year monitoring experiment: Biogeochemical implications, Mar. Chem., 120, 164-178, https://doi.org/10.1016/j.marchem.2009.02.004, 2010. 
Hamilton, D. S., Scanza, R. A., Feng, Y., Guinness, J., Kok, J. F., Li, L., Liu, X., Rathod, S. D., Wan, J. S., Wu, M., and Mahowald, N. M.: Improved methodologies for Earth system modelling of atmospheric soluble iron and observation comparisons using the Mechanism of Intermediate complexity for Modelling Iron (MIMI v1.0), Geosci. Model Dev., 12, 3835-3862, https://doi.org/10.5194/gmd-12-3835-2019, 2019.

Hauglustaine, D. A., Balkanski, Y., and Schulz, M.: A global model simulation of present and future nitrate aerosols and their direct radiative forcing of climate, Atmos. Chem. Phys., 14, 1103111063, https://doi.org/10.5194/acp-14-11031-2014, 2014.

Holben, B., Tanre, D., Smirnov, A., Eck, T. F., Slutsker, I., Abuhassan, N., Newcomb, W. W., Schafer, J., Chatenet, B., Lavenu, F., Kaufman, Y. J., Vande Castle, J., Setzer, A., Markham, B., Clark, D., Frouin, R., Halthore, R., Karnieli, A., O’Neill, N. T., Pietras, C., Pinker, R. T., Voss, K., and Zibordi, G.: An emerging ground-based aerosol climatology: Aerosol Optical Depth from AERONET, J. Geophys. Res., 106, 12067-12097, 2001.

Hong, S. Y., Dudhia, J., and Chen, S.: A revised approach to ice microphysical processes for the bulk parameterization of clouds and precipitation, Mon. Weather Rev., 132, 103-120, 2004.

Hong, S. Y., Noh, Y., and Dudhia, J.: A new vertical diffusion package with an explicit treatment of entrainment processes, Mon. Weather Rev., 134, 2318-2341, https://doi.org/10.1175/MWR3199.1, 2006.

Ito, A. and Shi, Z.: Delivery of anthropogenic bioavailable iron from mineral dust and combustion aerosols to the ocean, Atmos. Chem. Phys., 16, 85-99, https://doi.org/10.5194/acp-16-852016, 2016.

Ito, A., Myriokefalitakis, S., Kanakidou, M., Mahowald, N. M., Scanza, R. A., Hamilton, D. S., Baker, A. R., Jickells, T., Sarin, M., Bikkina, S., Gao, Y., Shelley, R. U., Buck, C. S., Landing, W. M., Bowie, A. R., Perron, M. M. G., Guieu, C., Meskhidze, N., Johnson, M. S., Feng, Y., Kok, J. F., Nenes, A., and Duce, R. A.: Pyrogenic iron: The missing link to high iron solubility in aerosols, Sci. Adv., 5, eaau7671, https://doi.org/10.1126/sciadv.aau7671, 2019.

Janssens-Maenhout, G., Crippa, M., Guizzardi, D., Dentener, F., Muntean, M., Pouliot, G., Keating, T., Zhang, Q., Kurokawa, J., Wankmüller, R., Denier van der Gon, H., Kuenen, J. J. P., Klimont, Z., Frost, G., Darras, S., Koffi, B., and Li, M.: HTAP_v2.2: a mosaic of regional and global emission grid maps for 2008 and 2010 to study hemispheric transport of air pollution, Atmos. Chem. Phys., 15, 11411-11432, https://doi.org/10.5194/acp-15-11411-2015, 2015.

Journet, E., Balkanski, Y., and Harrison, S. P.: A new data set of soil mineralogy for dust-cycle modeling, Atmos. Chem. Phys., 14, 3801-3816, https://doi.org/10.5194/acp-14-3801-2014, 2014.

Kandler, K., Benker, N., Bundke, U., Cuevas, E., Ebert, M., Knippertz, P., Rodriguez, S., Schutz, L., and Weinbruch, S.: Chemical composition and complex refractive index of Saharan Mineral Dust at Izana, Tenerife (Spain) derived by electron microscopy, Atmos. Environ., 41, 8058-8074, https://doi.org/10.1016/j.atmosenv.2007.06.047, 2007.

Kok, J. F., Parteli, E. J. R., Michaels, T. I., and Karam, D. B.: The physics of wind-blown sand and dust, Rep. Prog. Phys., 75, 106901, http://stacks.iop.org/0034-4885/75/i=10/a=106901 (last access: 29 November 2019), 2012.
Landing, W. M. and Paytan, A.: Marine chemistry special issue: Aerosol chemistry and impacts on the ocean, Mar. Chem., 120, 1-3, https://doi.org/10.1016/j.marchem.2010.04.001, 2010.

Lequy, E., Nicolas, M., Conil, S., and Turpault, M.: Relationship between atmospheric dissolved deposition and mineral dust deposition in French forests, Water Air Soil Poll., 224, 1680, https://doi.org/10.1007/s11270-013-1680-4, 2013.

Lohou, F., Kergoat, L., Guichard, F., Boone, A., Cappelaere, B., Cohard, J.-M., Demarty, J., Galle, S., Grippa, M., Peugeot, C., Ramier, D., Taylor, C. M., and Timouk, F.: Surface response to rain events throughout the West African monsoon, Atmos. Chem. Phys., 14, 3883-3898, https://doi.org/10.5194/acp-143883-2014, 2014.

Mahowald, N. M., Baker, A. R., Bergametti, G., Brooks, N., Duce, R. A., Jickells, T. D., Kubilay, N., Prospero, J. M., and Tegen, I.: Atmospheric global dust cycle and iron inputs to the ocean, Global Biogeochem. Cy., 19, GB4025, https://doi.org/10.1029/2004GB002402, 2005.

Mahowald, N. M., Hamilton, D. S., Mackey, K. R. M., Moore, J. K., Baker, A. R., Scanza, R. A., and Zhang, Y.: Aerosol trace metal leaching and impacts on marine microorganisms, Nat. Commun., 9, 2614, https://doi.org/10.1038/s41467-018-04970-7, 2018.

Mailler, S., Menut, L., Khvorostyanov, D., Valari, M., Couvidat, F., Siour, G., Turquety, S., Briant, R., Tuccella, P., Bessagnet, B., Colette, A., L'etinois, L., Markakis, K., and Meleux, F.: CHIMERE-2017: from urban to hemispheric chemistrytransport modeling, Geosci. Model Dev., 10, 2397-2423, https://doi.org/10.5194/gmd-10-2397-2017, 2017.

Menut, L., Schmechtig, C., and Marticorena, B.: Sensitivity of the sandblasting fluxes calculations to the soil size distribution accuracy, J. Atmos. Ocean. Technol., 22, 1875-1884, 2005.

Menut, L., Bessagnet, B., Khvorostyanov, D., Beekmann, M., Blond, N., Colette, A., Coll, I., Curci, G., Foret, G., Hodzic, A., Mailler, S., Meleux, F., Monge, J.-L., Pison, I., Siour, G., Turquety, S., Valari, M., Vautard, R., and Vivanco, M. G.: CHIMERE 2013: a model for regional atmospheric composition modelling, Geosci. Model Dev., 6, 981-1028, https://doi.org/10.5194/gmd-6-981-2013, 2013a.

Menut, L., Perez Garcia-Pando, C., Haustein, K., Bessagnet, B., Prigent, C., and Alfaro, S.: Relative impact of roughness and soil texture on mineral dust emission fluxes modeling, J. Geophys. Res., 118, 6505-6520, https://doi.org/10.1002/jgrd.50313, 2013b.

Menut, L., Rea, G., Mailler, S., Khvorostyanov, D., and Turquety, S.: Aerosol forecast over the Mediterranean area during July 2013 (ADRIMED/CHARMEX), Atmos. Chem. Phys., 15, 7897 7911, https://doi.org/10.5194/acp-15-7897-2015, 2015.

Menut, L., Siour, G., Mailler, S., Couvidat, F., and Bessagnet, B.: Observations and regional modeling of aerosol optical properties, speciation and size distribution over Northern Africa and western Europe, Atmos. Chem. Phys., 16, 12961-12982, https://doi.org/10.5194/acp-16-12961-2016, 2016.

Middleton, N.: Desert dust hazards: A global review, Aeolian Res., 24, 53-63, https://doi.org/10.1016/j.aeolia.2016.12.001, 2017.

Mlawer, E., Taubman, S., Brown, P., Iacono, M., and Clough, S.: Radiative transfer for inhomogeneous atmospheres: RRTM a validated correlated-k model for the longwave, J. Geophys. Res., 102, 16663-16682, 1997. 
Morman, S. A. and Plumlee, G. S.: The role of airborne mineral dusts in human disease, Aeolian Res., 9, 203-212, https://doi.org/10.1016/j.aeolia.2012.12.001, 2013.

Paris, R., Desboeufs, K., and Journet, E.: Variability of dust iron solubility in atmospheric waters: Investigation of the role of oxalate organic complexation, Atmos. Environ., 45, 6510-6517, https://doi.org/10.1016/j.atmosenv.2011.08.068, 2011.

Perlwitz, J. P., Pérez García-Pando, C., and Miller, R. L.: Predicting the mineral composition of dust aerosols - Part 1: Representing key processes, Atmos. Chem. Phys., 15, 11593-11627, https://doi.org/10.5194/acp-15-11593-2015, 2015.

Putaud, J.-P., Raes, F., Van Dingenen, R., Bruggemann, E., Facchini, M.-C., Decesari, S., Fuzzi, S., Gehrig, R., Huglin, C., Laj, P., Lorbeer, G., Maenhaut, W., Mihalopoulos, N., Muller, K., Querol, X., Rodriguez, S., Schneider, J., Spindler, G., Ten Brink, H., Torseth, K., and Wiedensohler, A.: A European aerosol phenomenology - 2: chemical characteristics of particulate matter at kerbside, urban, rural and background sites in Europe, Atmos. Environ., 38, 2579-2595, 2004.

Ravi, S., D’Odorico, P., Breshears, D. D., Field, J. P., Goudie, A. S., Huxman, T. E., Li, J., Okin, G. S., Swap, R. J., Thomas, A. D., Van Pelt, S., Whicker, J. J., and Zobeck, T. M.: Aeolian Processes and the Biosphere, Rev. Geophys., 49, rG3001, https://doi.org/10.1029/2010RG000328, 2011.

Rea, G., Turquety, S., Menut, L., Briant, R., Mailler, S., and Siour, G.: Source contributions to 2012 summertime aerosols in the Euro-Mediterranean region, Atmos. Chem. Phys., 15, 80138036, https://doi.org/10.5194/acp-15-8013-2015, 2015.

Richon, C., Dutay, J.-C., Dulac, F., Wang, R., Balkanski, Y., Nabat, P., Aumont, O., Desboeufs, K., Laurent, B., Guieu, C., Raimbault, P., and Beuvier, J.: Modeling the impacts of atmospheric deposition of nitrogen and desert dust-derived phosphorus on nutrients and biological budgets of the Mediterranean Sea, Prog. Oceanogr., 163, 21-39, https://doi.org/10.1016/j.pocean.2017.04.009, 2017.

Scanza, R. A., Mahowald, N., Ghan, S., Zender, C. S., Kok, J. F., Liu, X., Zhang, Y., and Albani, S.: Modeling dust as component minerals in the Community Atmosphere Model: development of framework and impact on radiative forcing, Atmos. Chem. Phys., 15, 537-561, https://doi.org/10.5194/acp-15-537-2015, 2015.

Seinfeld, J. H. and Pandis, S. N.: Atmospheric Chemistry and Physics: From Air Pollution to Climate Change, WileyInterscience, J. Wiley, New York, 1998.

Shao, Y., Wyrwoll, K.-H., Chappell, A., Huang, J., Lin, Z., McTainsh, G. H., Mikami, M., Tanaka, T. Y., Wang, X., and Yoon, S.: Dust cycle: An emerging core theme in Earth system science, Aeolian Res., 2, 181-204, https://doi.org/10.1016/j.aeolia.2011.02.001, 2011.

Skamarock, W., Klemp, J., Dudhia, J., Gill, D., Barker, D., Wang, W., and Powers, J.: A Description of the Advanced Research WRF Version 2, NCAR Technical Note, Boulder, Colorado, USA, NCAR/TN-468+STR, https://doi.org/10.5065/D68S4MVH, 2007.

Slinn, W.: Predictions for particle deposition to vegetation surfaces, Atmos. Environ., 23, 1293-1304, 1982.

Sokolik, I. N. and Toon, O. B.: Incorporation of mineralogical composition into models of the radiative properties of mineral aerosol from UV to IR wavelengths, J. Geophys. Res.-Atmos., 104, 9423-9444, https://doi.org/10.1029/1998JD200048, 1999.
Stuut, J.-B., Smalley, I., and O'Hara-Dhand, K.: Aeolian dust in Europe: African sources and European deposits, Quatern. Int., 198, 234-245, https://doi.org/10.1016/j.quaint.2008.10.007, 2009.

Tegen, I., Hollrig, P., Chin, M., Fung, I., Jacob, D., and Penner, J.: Contribution of Different Aerosol Species to the Global Aerosol Extinction Optical Thickness: Estimates From Model Results, J. Geophys. Res., 102, 23895-23915, 1997.

Turquety, S., Menut, L., Bessagnet, B., Anav, A., Viovy, N., Maignan, F., and Wooster, M.: APIFLAME v1.0: highresolution fire emission model and application to the EuroMediterranean region, Geosci. Model Dev., 7, 587-612, https://doi.org/10.5194/gmd-7-587-2014, 2014.

Utry, N., Ajtai, T., Pintér, M., Tombácz, E., Illés, E., Bozóki, Z., and Szabó, G.: Mass-specific optical absorption coefficients and imaginary part of the complex refractive indices of mineral dust components measured by a multi-wavelength photoacoustic spectrometer, Atmos. Meas. Tech., 8, 401-410, https://doi.org/10.5194/amt-8-401-2015, 2015.

Von Storch, H., Langenberg, H., and Feser, F.: A spectral nudging technique for dynamical downscaling purposes, Mon. Weather Rev., 128, 3664-3673, 2000.

Wang, R., Balkanski, Y., Boucher, O., Bopp, L., Chappell, A., Ciais, P., Hauglustaine, D., Peñuelas, J., and Tao, S.: Sources, transport and deposition of iron in the global atmosphere, Atmos. Chem. Phys., 15, 6247-6270, https://doi.org/10.5194/acp15-6247-2015, 2015.

Wang, Y., Sartelet, K. N., Bocquet, M., Chazette, P., Sicard, M., D’Amico, G., Léon, J. F., Alados-Arboledas, L., Amodeo, A., Augustin, P., Bach, J., Belegante, L., Binietoglou, I., Bush, X., Comerón, A., Delbarre, H., García-Vízcaino, D., GuerreroRascado, J. L., Hervo, M., Iarlori, M., Kokkalis, P., Lange, D., Molero, F., Montoux, N., Muñoz, A., Muñoz, C., Nicolae, D., Papayannis, A., Pappalardo, G., Preissler, J., Rizi, V., Rocadenbosch, F., Sellegri, K., Wagner, F., and Dulac, F.: Assimilation of lidar signals: application to aerosol forecasting in the western Mediterranean basin, Atmos. Chem. Phys., 14, 12031-12053, https://doi.org/10.5194/acp-14-12031-2014, 2014.

Wild, O., Zhu, X., and Prather, M. J.: Fast-J: Accurate Simulation of In- and Below-Cloud Photolysis in Tropospheric Chemical Models, J. Atmos. Chem., 37, 245-282, 2000.

Willis, P. and Tattelman, P.: Drop-size distributions associated with intense rainfall, J. Appl. Meteorol., 28, 3-15, https://doi.org/10.1175/15200450(1989)028<0003:DSDAWI>2.0.CO;2, 1989.

Zhang, L., Gong, S., Padro, J., and Barrie, L.: A size-segregated particle dry deposition scheme for an atmospheric aerosol module, Atmos. Environ., 35, 549-560, 2001.

Zhang, Y., Mahowald, N., Scanza, R. A., Journet, E., Desboeufs, K., Albani, S., Kok, J. F., Zhuang, G., Chen, Y., Cohen, D. D., Paytan, A., Patey, M. D., Achterberg, E. P., Engelbrecht, J. P., and Fomba, K. W.: Modeling the global emission, transport and deposition of trace elements associated with mineral dust, Biogeosciences, 12, 5771-5792, https://doi.org/10.5194/bg-125771-2015, 2015. 